\title{
A EFETIVIDADE DO TERMO DE AJUSTAMENTO DE CONDUTA (TAC) COMO INSTRUMENTO DE REPARAÇÃO DO MEIO AMBIENTE: UMA ANÁLISE DO CASO DE MARIANA/MG*
}

Fernanda da Luz Berna**

\section{INTRODUÇÃO}

O presente artigo irá abordar o posicionamento da doutrina de direito ambiental, acerca da utilização do Termo de Ajustamento de Conduta (TAC), como instrumento efetivo de reparação de danos ambientais, analisando, a sua aplicação e efetividade no caso ocorrido em Mariana/MG, em novembro de 2015.

Tendo em vista a busca do desenvolvimento econômico na atualidade, a sociedade moderna possui o dever de observar os limites existentes para a garantia de um meio ambiente ecologicamente equilibrado, devendo zelar por este preceito, haja vista se tratar de um bem de uso comum e essencial a uma qualidade de vida saudável, o qual pertence não somente a geração presente, mas, também, às gerações futuras, conforme dispõe o art. 225, caput, da Constituição Federal.

A tutela constitucional do meio ambiente estabelece deveres à coletividade e ao Poder Público. Dito de outro modo, a

\footnotetext{
* Artigo apresentado ao Curso de Bacharelado em Direito do Centro Universitário Metodista - IPA, como requisito parcial para obtenção do Grau de Bacharel em Direito. Orientador: Prof. Dr. Rogério Santos Rammê.

** Bacharela em Direito pelo Centro Universitário Metodista - IPA
} 
Constituição Federal de 1988 impõe não somente à coletividade, mas também ao Poder Público, o dever de defender e preservar o equilíbrio ecológico do meio ambiente, prerrogativa esta que pode ser exercida através do Ministério Público, consoante determinação do art. 129, III, da Carta Magna, por meio de inquérito civil ou ação civil pública.

Dessa maneira, o presente trabalho busca analisar os regramentos contidos na Constituição Federal e na legislação ambiental infraconstitucional referentes à responsabilidade civil em matéria ambiental, bem como a utilização do Termo de Ajustamento de Conduta (TAC), intermediado pelo Ministério Público nas ações civis públicas ambientais, como instrumento efetivo de reparação do dano ambiental, elegendo, como modelo de análise, sua utilização no caso ocorrido em Mariana/MG. Busca-se verificar se, no caso referido, a celebração do TAC se mostra adequada para a reparação do dano ambiental ocorrido.

Com efeito, o problema de pesquisa que norteou a presente investigação é o seguinte: considerando o Termo de Ajustamento de Conduta realizado entre o Ministério Público e as empresas poluidoras no caso ocorrido em Mariana/MG, no ano de 2015, pode-se dizer que tal compromisso foi medida apropriada para a resolução dessa situação e que os ajustes e medidas reparatórias e/ou compensatórias firmadas foram razoáveis e adequadas à reparação do meio ambiente lesado, tendo em vista a dimensão do dano causado?

De início, entende-se que a busca por um meio consensual para a resolução de conflitos é uma tendência no direito processual brasileiro, principalmente no que tange a conflitos de extrema complexidade relacionados a direitos difusos, como ocorre nas tratativas envolvendo a tragédia de Mariana/MG.

Logo, a intenção de se efetuar um termo de ajustamento de conduta é, justamente, dar mais celeridade processual, haja vista 
que um procedimento ordinário de uma ação civil pública traria demasiada morosidade para sua resolução.

Todavia, ainda não foi efetuado um termo definitivo, uma vez que não se pode auferir, de maneira precisa, o dano e as suas consequências diante da magnitude do desastre ocorrido com o rompimento da barragem de Fundão e Santarém.

Assim, tornou-se necessária a formulação de um "termo de ajustamento provisório", com o intuito de realizar um diagnóstico socioambiental e econômico, para que se possa identificar, de maneira mais minuciosa, a dimensão dos danos e, futuramente, definir as diretrizes reais e parâmetros para o acordo definitivo.

Dessa forma, com uma verificação precisa da lesão socioambiental causada, através de estudos técnicos realizados por experts, haverá maior detalhamento informativo sobre a extensão do dano provocado, o que servirá, por certo, para a elaboração de um acordo que atenda às reais necessidades dos locais atingidos, bem como para quantificar, minuciosamente, o valor indispensável para arcar com os custos da reparação integral do dano ambiental ocorrido.

A pesquisa objetiva, portanto, não apenas analisar o instituto da responsabilidade civil ambiental, com suas particularidades, mas, sobretudo, abordar a utilização do Termo de Ajustamento de Conduta como instrumento de reparação do dano ambiental no direito brasileiro, tomando como exemplo de sua utilização o caso de Mariana/MG.

Trata-se de pesquisa qualitativa, que se utilizou de dados documentais, doutrinários e jurisprudenciais referentes ao tema da pesquisa. Adotou-se também o caso ocorrido em Mariana/MG como modelo de análise. 0 método de pesquisa utilizado foi o hipotético-dedutivo.

A narrativa foi desenvolvida da seguinte forma: na primeira etapa, a pesquisa analisa o instituto da responsabilidade civil ambiental, buscando identificar seus fundamentos e princípios 
gerais para determinar o papel a ser desempenhado pelo termo de ajustamento de conduta (TAC) como um dos instrumentos voltados à reparação de danos ambientais. Na sequência, volta-se ao estudo da aplicação do TAC firmado no caso de Mariana/ MG, para concluir sobre sua efetividade enquanto instrumento de reparação do dano ambiental ocorrido.

\section{RESPONSABILIDADE CIVIL E DAS FORMAS DE REPARAÇÃO}

A responsabilidade civil pelo dano ambiental no Brasilestá regrada no plano infraconstitucional federal há quase quatro décadas, conforme dispõe o art. $14, \S 1^{\circ}$, da Lei 6.938/81. Mas é a partir da Constituição Federal de 1988 que o instituto da responsabilidade civil ambiental passou a ter a função específica de servir à reparação do dano ambientalcom o intuito de proteção à qualidade dos ecossistemas, independentemente de qualquer utilidade ou benefício humano direto. Dito de outro modo: "a responsabilidade civil pelo dano ambiental, possui uma função social que ultrapassa as finalidades punitiva, preventiva e reparatória, normalmente atribuídas ao instituto." ${ }^{1}$

Destaca-se que a ideia de proteção ao meio ambiente no direito brasileiro surge a partir de uma função de ordem pública ambiental, onde o Estado possui a prerrogativa de assegurar o equilíbrio, de forma harmônica, entre a sociedade e seu ambiente. Além do mais, o caput, do art. 225, da Constituição Federal, dá ao meio ambiente um caráter de patrimônio público, impondo uma responsabilização solidária ao Poder Público e à coletividade quanto sua proteção, a fim de que todos possam lograr de uma qualidade de vida saudável. ${ }^{2}$

1 STEIGLEDER, Annelise Monteiro. Responsabilidade Civil Ambiental: As dimensões do dano ambiental no direito brasileiro. 2.ed. Porto Alegre: Livraria do Advogado Editora, 2011, p. 155.

2 MILARÉ, Édis. Direito do ambiente: doutrina, jurisprudência, glossário. 5.ed. São Paulo: Editora Revista dos Tribunais, 2007, p. 764-765. 
Ainda, o $§ 3^{\circ}$, do referido dispositivo constitucional supracitado, acaba adotando um regime de tríplice responsabilização, no qual, determina a responsabilidade civil ambiental ao poluidor - obrigação de reparar os danos causados - de forma independentemente, mas cumulativa, às responsabilidades penais e administrativas que porventura decorram da conduta dos agentes poluidores.

Na sequência, buscar-se-á, discorrer com mais detalhes sobre o instituto da responsabilidade civil ambiental no direito pátrio, bem como sobre as principais formas de reparação de danos ambientais no Brasil.

\subsection{RESPONSABILIDADE CIVIL AMBIENTAL}

Como já destacado, da análise do parágrafo $3^{\text {o }}$ do art. 225, da Constituição Federal de 1988, observa-se a adoção do regime jurídico-constitucional da tríplice responsabilização pelo dano ambiental (responsabilidades civil, penal e administrativa, todas independentes entre si).Segundo Yoshida ${ }^{3}$, o tratamento da responsabilidade pelo dano ambiental possui um caráter pedagógico e preventivo à reiteração do ato danoso ao ambiente. Contudo, Steigleder ${ }^{4}$ entende que com o reconhecimento da importância do direito ao meio ambiente ecologicamente equilibrado, a responsabilidade civil ambiental passa a ser percebida como dotadade uma função nova, social, a qual transcende o caráter punitivo, preventivo e reparatório normalmente atribuídas à responsabilidade civil tradicional.

Em regra, o instituto da responsabilidade civil tem por objetivo tão somente a reparação dos danos e a punição do respon-

3 YOSHIDA, Consuelo Yatsuda Moromizato. A efetividade e eficiência ambiental dos instrumentos econômicos-financeiros e tributários. Ênfase na prevenção. A utilização econômica dos bens ambientais e suas implicações. In: TÔRRES, Heleno Taveira (Org.). Direito tributário ambiental. São Paulo: Malheiros, 2005, p. 545. Apud SIRVINSKAS, Luís Paulo. Tutela constitucional do meio ambiente. São Paulo: Saraiva, 2008, p. 46.

4 STEIGLEDER, 2011, p. 155. 
sável, não tendo como escopo a prevenção de riscos ou mesmo redefinição do modus operandi empregado na ação danosa. ${ }^{5}$ Nesse sentido, como salienta Ferreira, a ideia central da responsabilidade civil tradicional é "a preocupação de evitar a subsistência de um prejuízo injusto, impondo uma deslocação patrimonial do lesante para o lesado". ${ }^{6}$

Ocorre que com o advento da Constituição Federal de 1988houve o reconhecimento da fundamentalidade do direito ao meio ambiente ecologicamente equilibrado. E mais, passou-se a fundamentar na própria Constituição Federal a obrigação de reparar os danos praticados ao meio ambiente ecologicamente equilibrado. Com isso as tradicionais funções do instituto da responsabilidade civil, em se tratando de reparação de danos ambientais, foram alargadas, contemplando "à consecução de valores protegidos na Constituição, tais como o bem social e a dignidade da pessoa humana - não apenas do lesado individual, mas do gênero humano." ${ }^{7}$ Como reflexo dessa ampliação que advém da função social da responsabilidade civil ambiental, supera-se o paradigma individualista dos institutos tradicionais do direito privado, como é o caso da responsabilidade civil. Assume a responsabilidade civil ambiental, nesse contexto, uma função preventiva marcante.

Dessa forma, é de extrema importância abordar dois dos princípios basilares do direito ambiental, que são informativos da responsabilidade civil ambiental: os princípios da precaução e da prevenção. Embora se tratem de conceitos antigos no ordenamento jurídico ambiental mundial, ganharam grande força no âmbito nacional na década de 90, com a Declaração do Rio sobre Meio Ambiente e Desenvolvimento e da Convenção sobre Diversidade Biológica, ambas ocorridas em 1992.

\footnotetext{
5 STEIGLEDER, 2011, p. 155.

6 FERREIRA. Henrique Felipe. Fundamentos da responsabilidade civil. Dano injusto e ato ilícito. Revista de Direito privado, São Paulo, n. 3, p. 115, jul./set. 2000. Apud STEIGLEDER, 2011, p. 155-156.

7 STEIGLEDER, op. cit., p. 156.
} 
O princípio da precaução trabalha com a pretensão de se evitar um risco futuro e incerto, ou seja, quando não há certeza científica da potencialidade ou existência da degradação ${ }^{8}$, todavia, conforme dispõe o Princípio $15^{9}$, da Declaração do Rio de 92, havendo indício de dano grave ou irreversível ao meio ambiente, o Estado deverá agir impondo medidas econômicas, de forma antecipada, para prevenir a degradação.

Já no tocante ao princípio da prevenção, este determina que a partir da certeza do potencial lesivo e seus efeitos de determinada atividade, esta deverá sofrer intervenção com a finalidade de cessá-la para sua recuperação ecológica ${ }^{10}$. Isto é, em tendo sido tomada a decisão pela admissão do risco, impõe-se a adoção de medidas de forma preventiva para evitar a produção daquele dano ou de sua repetição. ${ }^{11}$

Nesta senda, há de se salientar a importância do princípio do poluidor-pagador, na qual é pacífica a jurisprudência de nos-

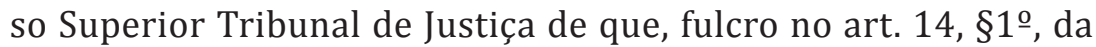
Lei 6.938/1981, o infrator, em decorrência do referido princípio, previsto no art. 4, VII (primeira parte), do mesmo diploma legal, "é obrigado, independentemente da existência de culpa, a reparar todos os danos que cause ao meio ambiente e a terceiros afetados por sua atividade".Logo, é desnecessária a arguição acerca do elemento subjetivo do agente poluidor, o que, resulta, na irrelevância dos institutos da boa ou má-fé "para fins de acertamento

8 RODRIGUES, Marcelo Abelha. Instituições de Direito Ambiental: parte geral. São Paulo: Max Limonad, 2002, p. 150. Apud ANTUNES, Paulo de Bessa. Direito Ambiental. 14.ed. São Paulo: Atlas, 2012, p. 31.

9 Com o fim de proteger o meio ambiente, o princípio da precaução deverá ser amplamente observado pelos Estados, de acordo com suas capacidades. Quando houver ameaça de danos graves ou irreversíveis, a ausência de certeza científica absoluta não será utilizada como razão para o adiamento de medidas economicamente viáveis para prevenir a degradação ambiental.

10 SARLET, Ingo Wolfgang; FEINSTERSEIFER, Tiago. Princípios do direito ambiental. São Paulo: Saraiva, 2014, p. 160-161.

11 STEIGLEDER, 2011, p. 165. 
da natureza, conteúdo e extensão dos deveres de restauração do status quo ante ecológico e de indenização".12

Podemos dizer, ainda, que a reparação e a repressão do dano ambiental são informadas pelo princípio do poluidor-pagador, no sentido de também abranger a imposição, ao poluidor,da internalização dos custos de prevenção à prática ou repetição do dano ecológico cometido, a fim de evitar que as despesas da degradação ocorrida recaiam, de forma injusta, sobre toda sociedade. ${ }^{13}$

Partindo, então, do que já foi exposto, podemos observar que a reponsabilidade pelo dano ambiental, no direito brasileiro,

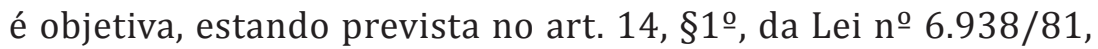
tendo sido posteriormente recepcionada pela Constituição Federal de 1988 , em seu art. 225, § $3^{\circ}$, ganhando assim fundamentação constitucional e uma função social marcada por seu traço solidarizante e preventivo. A esse respeito, a lição de Steigleder, ao afirmar que a responsabilidade civil pelo dano ambiental:

[...] tem como pressuposto a existência de uma atividade que implique riscos para a saúde e para o meio ambiente, impondo-se ao empreendedor a obrigação de prevenir tais riscos (princípio da prevenção) e de internalizá-los em seu processo produtivo (princípio do poluidor-pagador). Pressupõe, ainda, o dano ou risco de dano e o nexo de causalidade entre a atividade e o resultado, efetivo ou potencial. ${ }^{14}$

Consequentemente, a definição do nexo causal, é requisito de suma importância, uma vez que a responsabilidade poderá ser imputada ao poluidor sem que o mesmo tenha tido a intenção de causar o dano. Esse, aliás, é o entendimento dominante no Supe-

12 BRASIL, Superior Tribunal de Justiça. Recurso Especial n ${ }^{\circ} 769.753 /$ SC, Relator Ministro Herman Benjamin, Segunda Turma, Julgado em 08/09/2009, DJe 10/06/2011.

13 SARLET; FENSTERSEIFER, op.cit., p. 85.

14 STEIGLEDER, 2011, p. 171. 
rior Tribunal de Justiça: para se apurar o nexo de causalidade, no que diz respeito ao dano ambiental, "equiparam-se: quem faz, quem não faz quando deveria fazer, quem deixa de fazer, quem não se importa que façam, quem financia para que façam, e quem se beneficia quando os outros fazem". ${ }^{15}$

Nesse sentido, importante ressaltar que o direito ambiental brasileiro adotou, de forma majoritária, a teoria do risco integral para a imputação da responsabilidade civil ao poluidor. Logo, analisa-se a existência do dano e o vínculo causal, dispensando a avaliação da vontade do agente ${ }^{16}$, ou seja, basta que se ocorra determinado dano e se prove o vínculo causal para que se configure a responsabilidade sobre a degradação ambiental e se assegure o direito a sua reparação. ${ }^{17}$

Destarte, segundo descreve Steigleder ${ }^{18}$, a reponsabilidade pelo risco se destina tanto para os danos gerados pelas atividades perigosas como àqueles provocados por uma atividade comum, portanto, a ideia da teoria do risco é de que quem exerce uma atividade econômica possui o dever de arcar com todos e quaisquer custos referentes à prevenção e à reparação dos danos ambientais, independentemente se já o tenha ocorrido ou que poderá vir a acontecer, utilizando-se do princípio alterumneminemlaedere $e^{19}$.

15 BRASIL, Superior Tribunal de Justiça. Recurso Especial no 650.728/SC, Relator Herman Benjamin, Segunda Turma, julgado em 23/10/2007, DJe 02/12/2009.

16 SIRVINSKAS, 2008, p. 44-45.

17 MILARÉ, 2007, p. 897.

18 STEIGLEDER, op.cit., p. 176.

19 Sobre o princípio alterumneminemlaedere esclarece Carlos Eduardo Silva e Souza: "O princípio do neminemlaedere, ou seja, a noção de não lesar outrem, em que pese seus registros históricos mais longínquos, encontra guarida na Constituição da República Federativa do Brasil, especificamente em seu artigo $5^{\circ}, \mathrm{XXXV}$, ao não permitir a exclusão do Poder Judiciário a ameaça de direito, já que a concretização dos danos geradora de efeitos de difícil reversibilidade ou de irreversibilidade. O princípio do neminemlaedere encontra sintonia com a noção de prevenção e precaução contida no Direito Ambiental, razão pela qual pode ser compreendida como elemento adicional na proteção do meio ambiente. A evolução dos paradigmas demonstrou que estes migraram do século XIX ao presente para das premissas de responsabilidade, solidariedade para chegar à segurança, sendo que esta última 
No entanto, muito embora haja muita receptividade doutrinária e jurisprudencial no que tange a utilização da teoria do risco integral na esfera ambiental, ela não é, no entanto, irrefutável, sendo contraposta pela teoria do risco criado, a qual se diferencia pela admissibilidade de excludentes de responsabilidade civil, tratando-se da culpa exclusiva da vítima, de fatos de terceiros e de força maior. ${ }^{20}$

desempenha perspectiva chave na sociedade de massa, especialmente quando se considera o dever de equidade intergeracional em relação ao bem ambiental; $\mathrm{O}$ princípio do neminemlaedere pode servir não somente para a busca da ação mais desejada, qual seja: a prevenção dos danos ambientais, mas também para que o elemento preventivo também possa constar na fixação da reparação, a fim de que degradador/poluidor e a própria sociedade como um todo possam se sentir desencorajados a praticar condutas que possam implicar em lesões ao meio ambiente." (SOUZA, Carlos Eduardo Silva e. O princípio neminemlaedere e a prevenção dos danos ambientais. [S.1: s.n], 2012, p. 13-14)

20 SIRVINSKAS, Luís Paulo. Manual de direito ambiental.12.ed. São Paulo: Saraiva, 2011, p. 260-261. Ainda sobre a diferença entre teoria do risco criado e teoria do risco integral merece destaque a lição de Steigleder: "No Brasil, um dos critérios de imputação que tem sido utilizados é a teoria do risco integral, por meio da qual a criação do risco seria suficiente para a imputação, sem exigência de se comprovar que a atividade guarda adequação causal adequada com o dano ou possui vínculo direto com este. [...] Apesar da receptividade doutrinária e jurisprudencial, adoção da teoria do risco integral na seara ambiental não é, todavia, pacífica, sendo contraposta pela teoria do risco criado, cujo diferencial mais evidente é a admissibilidade das excludentes de responsabilidade civil culpa exclusiva da vítima, fatos de terceiros e força maior -, posto que tais fatos têm o condão de romper o curso causal, construindo por si mesmos, as causas adequadas do evento lesivo. A teoria do risco criado, alinhada com a teoria da causalidade adequada, utilizada para explicar o liame causal, tem no elemento perigo a sua noção central. Trata-se da teoria acolhida pelo art. $4^{\circ}$ da Diretiva 2.004/35-CE do Parlamento Europeu e do Conselho, quando assevera que 'a presente diretiva não abrange danos ambientais, nem ameaças iminentes desses danos, causador por: a) atos de conflito armado, hostilidades, guerra civil ou insurreição; b) fenômenos naturais de caráter excepcional, inevitável e irresistível'. Também foi acolhida no art. 927, parágrafo único, do Código Civil Brasileiro. Na hipótese da Lei ${ }^{\circ} 6.938 / 81$, como não há restrição do regime de responsabilidade objetiva às atividades perigosas, deve-se observar que a sua incidência é ampla, percebendo-se a opção valorativa do sistema pela reparação do dano ambiental. Ou seja, não é a periculosidade da atividade que justifica o regime especial de responsabilidade, mas as peculiaridades do dano ambiental e o seu âmbito de proteção, fundado em direito fundamental. Portanto a responsabilidade pelo risco aplica-se tanto aos danos gerados por atividades perigosas como àqueles desencadeados por uma atividade profissional qualquer, partindo-se ainda 
Sendo assim, depois de feitas as devidas ponderações acerca da responsabilidade civil ambiental no ordenamento jurídico brasileiro, passa-se ao estudo das formas de reparação aos danos ambientais, as quais o poluidor-infrator estará sujeito quando configurada sua responsabilidade pela lesão ecológica causada.

\subsection{FORMAS DE REPARAÇÃO DO DANO AMBIENTAL}

Como já foi citado anteriormente, o direito ambiental brasileiro elegeu, de forma majoritária, a teoria do risco integral no que diz respeito ao dano ambiental, estabelecendo, assim, a responsabilidade civil objetiva do poluidor por seus danos causados, conforme dispõe o §3ำ, do art. 225, da Constituição Federal e o art. $14, \S 1^{\circ}$, da Lei $\mathrm{n}^{\circ}$ 6.938/81, ou seja, independentemente da existência de culpa.

Portanto, se torna totalmente dispensável o apontamento de que determinada atividade apresente risco direto ou que seja notoriamente perigosa, tal qual uma usina nuclear ou uma empresa que manuseie produtos químicos, haja vista que a responsabilidade civil objetiva em matéria ambiental imputa o dever jurídico de reparar o meio ambiente degradado a quem tenha o causado. ${ }^{21}$

Carbonnier ${ }^{22}$, em complemento, assevera que a adoção da teoria do risco integral no ordenamento jurídico não possui a pretensão de analisar os atos do infrator em relação ao dano

do princípio do alterumneminemlaedere. Ademais, as externalidades negativas não são geradas apenas por atividades perigosas, constituindo característica da sociedade de riscos contemporânea, que necessita de um sistema eficiente de canalização de responsabilidade, evitando-se a socialização dos riscos." (STEIGLEDER, Annelise Monteiro. Responsabilidade Civil Ambiental: as dimensões do dano ambiental no direito brasileiro. Porto Alegre: Livraria do Advogado Editora, 2011, p. 173-176)

21 MACHADO, Paulo Affonso Leme. Direito Ambiental Brasileiro.22.ed. São Paulo: Editora Malheiros. 2014, p. 403.

22 CARBONNIER apud Caio Mário da Silva Pereira. Responsabilidade civil Rio de Janeiro: Forense, 1990, p. 24. Apud FIORILLO, Celso Antônio Pacheco. Curso de direito ambiental brasileiro.12.ed. São Paulo: Editora Saraiva, 2011, p. 98. 
causado, pois é suficiente a constatação de que dano tenha relação material com o ato praticado, afinal, quem "exerce uma atividade deve assumir os riscos", sendo eles inerentes ou não a ela.

Sendo assim, confirmada a responsabilidade civil pela prática de determinado dano ambiental, não resta outro caminho senão o da sua reparação integral, no qual deverá ser o mais abrangente possível, no sentido de se considerar o maior número fatos da singularidade dos bens ambientais lesados, da impossibilidade de se quantificar o preço da vida e, acima disso, como forma de lição pedagógica para que o poluidor e própria sociedade aprendam a respeitar o meio ambiente. ${ }^{23}$

Para que seja feita a reparação do dano ambiental de forma integral, o dever de reparar deverá ser fundado no princípio do poluidor-pagador, uma vez que o responsável pelo cometimento da lesão deve internalizar todos os custos, independentemente se forem relacionados à prevenção ou a reparação da degradação. ${ }^{24}$

Importante ressaltar que princípio do poluidor-pagador consiste em duas vertentes, onde uma possui um caráter preventivo, buscando evitar uma possível ocorrência de dano ecológico; e a outra tem uma finalidade repressiva, pois visa a imposição da reparação pelo poluidor responsável da degradação ocorrida. ${ }^{25}$

Nessa senda, a legislação brasileira dispõe duas formas de reparação do meio ambiente degradado através, sendo elas: a reparação in natura e a indenização pecuniária. No entanto, isso não quer dizer que o julgador deva escolher entre uma alternativa o outra. Na verdade, se torna necessária, primeiramente, a apuração da possibilidade de retorno ao status quo ante, através da reparação natural. In casu de averiguada a impossibilidade de reversão do dano, a condenação deverá recair sobre o ressarcimento pecuniário. ${ }^{26}$

\footnotetext{
23 STEIGLEDER, 2011, p. 211.

24 STEIGLEDER, 2011, p. 211.

25 FIORILLO, op.cit., p. 92.

26 FIORILLO, 2011, p. 99.
} 
É indispensável ressaltar, ainda, que a reparação in natura se divide sob duas óticas, sendo elas a restituição e a recuperação, sendo a primeira concernente à restituição de um ecossistema ou de uma população silvestre lesada o mais próximo possível do status quo ante, enquanto a segunda se trata da impossibilidade de restituição desse ecossistema ou dessa população silvestre à sua condição originária. Dessa forma, quando nos referirmos à recuperação do meio ambiente degradado, estamos optando por uma forma de compensação ecológica, isto é, uma substituição de equivalência funcional. ${ }^{27}$

Não menos importante, também, no que tange aos pedidos de reparação pelo dano ambiental, é o fato de que poderá ser cumulada a obrigação de fazer juntamente com a indenização pecuniária, inocorrendobis in idem, haja vista que seus fundamentos são diversos, ou seja, um trata da reparação in natura do dano ecológico, enquanto o outro tem o intuito de ressarcir os danos materiais irreversíveis, bem como os danos imateriais porventura causados. ${ }^{28}$ Nesse sentido, colaciona-se precedente do Superior Tribunal de Justiça:

PROCESSO CIVIL. DIREITO AMBIENTAL. AÇÃO CIVIL PÚBLICA PARA TUTELA DO MEIO AMBIENTE. OBRIGAÇÕES DE FAZER, DE NÃO FAZER E DE PAGAR QUANTIA. POSSIBILIDADE DE CUMULAÇÃO DE PEDIDOS ART. 3 DA LEI 7.347/85. INTERPRETAÇÃO SISTEMÁTICA. ART. 225, § 3ํ, DA CF/88, ARTS. 2 E 4 DA LEI 6.938/81, ART. 25, IV, DA LEI 8.625/93 E ART. 83 DO CDC. PRINCÍPIOS DA PREVENÇÃO, DO POLUIDOR-PAGADOR E DA REPARAÇÃO INTEGRAL.

1. 0 sistema jurídico de proteção ao meio ambiente, disciplinado em normas constitucionais (CF, art. 225, § $3^{\circ}$ ) e infraconstitucionais (Lei 6.938/81, arts. $2^{\circ}$ e $4 \stackrel{\circ}{0}$ ), está fundado, entre outros, nos

27 STEIGLEDER, 2011, p. 213.

28 Ibidem., p. 212. 
princípios da prevenção, do poluidor-pagador e da reparação integral. Deles decorrem, para os destinatários (Estado e comunidade), deveres e obrigações de variada natureza, comportando prestações pessoais, positivas e negativas (fazer e não fazer), bem como de pagar quantia (indenização dos danos insuscetíveis de recomposição in natura), prestações essas que não se excluem, mas, pelo contrário, se cumulam, se for o caso. [...]. ${ }^{29}$

Isso se dá justamente porque a atividade que contribui para a poluição de determinado ecossistema acaba por violar o direito de outrem de desfrutar de um meio ambiente ecologicamente equilibrado, isto é, "o direito de alguém em respirar ar puro, beber água saudável e viver com tranquilidade". Logo por isso, é imprescindível que se oportunize a reparação in natura do dano ambiental, uma vez que somente uma indenização pecuniária seria insuficiente para o resgate desse direito fundamental. ${ }^{30}$

A esse respeito, Fiorillodestaca que a eventualidade de ressarcimento por danos materiais e/ou extrapatrimoniais não possui a capacidade de eximir a reparação específica do dano ambiental, uma vez que o direito a um meio ambiente ecologicamente equilibrado se trata de um direito difuso e, portanto, pertencente a toda uma coletividade. ${ }^{31}$

$\mathrm{Amado}^{32}$ traz, também, a reflexão, no tocante à indenização pecuniária, de que a valoração monetária do dano ambiental é demasiadamente complexa, isto quando não houver a chance da reparação ou a compensação, uma vez que não há como mensurar os valores dos bens ambientais. Logo, ficamos diante

29 Superior Tribunal de Justiça. Recurso Especial nº 605.323/MG, Relator Ministro José Delgado, Relator para Acórdão: Ministro Teori Albino Zavascki, Primeira Turma, julgado em 18/08/2005, DJ 17/10/2005, p. 179.

30 MACHADO, 2014, p. 403.

31 FIORILLO, 2011, p. 100.

32 AMADO, Frederico Augusto Di Trindade. Direito ambiental esquematizado.6.ed. São Paulo: Método, 2015, p. 884-885. 
de um dilema: como conseguir contabilizar o valor de onze toneladas de peixes mortos, com o rompimento da barragem em Mariana? ${ }^{33}$ Como medir o impacto da contaminação da água, pelos resíduos tóxicos, nas comunidades ribeirinhas abastecidas pelo rio Doce?

Sendo assim, compreende-se que a estipulação pecuniária da degradação ecológica deverá levar em consideração a gravidade da lesão ao meio ambiente e à coletividade, o prazo que o ecossistema levará para se recompor, caso haja viabilidade para a restituição in natura, e a afetação direta das pessoas atingidas pelo dano. ${ }^{34}$

Por fim, pode-se afirmar que resta consolidado na doutrina e jurisprudência que tanto a reparação in natura - em qualquer das suas modalidades, restituição ou recuperação - que implica obrigações de fazer, e a indenização pecuniária, que implica ressarcimento pelos danos ambientais materiais irreversíveis e pelos danos ambientais extrapatrimoniais.

A adoção dessas diferentes formas para se alcançar a reparação do meio ambiente degradado, coaduna-se com o preceito contido no princípio 15, da Declaração do Rio de Janeiro/92, o qual estipula ao Estado o dever de promover medidas de precaução ao meio ambiente e que, nos casos de danos graves ou irreversíveis, deverão ser adotadas medidas efetivas com o intuito de prevenir mais ainda a degradação ecológica do ambiente lesado.

Nesse sentido, a reparação in natura é a oportunidade, mediante um projeto de restituição do ambiente degradado, o qual terá a finalidade de implementar novamente os benefícios funcionais que já existiam naquele ecossistema antes da ocorrência do dano, se igualando à situação anterior ${ }^{35}$, ou ainda, na elaboração de projeto com o intuito de realizar uma compensação ecológica, isto é, adotando medida ecológica compensatória equivalente

33 BRANCO, Acesso em: 07.jun.2017.

34 AMADO, op. cit., p. 885.

35 STEIGLEDER, 2011, p. 217. 
às perdas decorrentes do dano, medidas essas que devem ser adotadas, preferencialmente, na região atingida pela degradação.

$\mathrm{E}$, ainda, na insuficiência de se conseguir igualar ou assemelhar o ambiente ao status quo ante, ao poluidor recairá a obrigação de arcar com uma indenização pecuniária, a qual deverá contemplar "os aspectos da degradação e dos danos extrapatrimoniais associados, tais como a perda imposta à qualidade de vida, a privação temporária para a fruição do bem e o valor de existência dos bens ambientais degradados". ${ }^{36}$

Analisados os principais aspectos da responsabilidade civil pelo dano ambiental e suas formas de reparação no direito brasileiro, avança-se, a seguir, sobre o termo de ajustamento de conduta (TAC) e sua utilização como instrumento apto a produzir uma adequada medida reparatória ao meio ambiente degradado, em menor tempo.

\section{TERMO DE AJUSTAMENTO DE CONDUTA (TAC)}

0 termo de ajustamento de conduta (TAC) teve sua origem no início da década de 80 , período este marcado pela grande evolução no direito ambiental. ${ }^{37}$ A partir desse eminente desenvolvimento na legislação brasileira, o Ministério Público passou a adquirir imensa relevância no cenário jurídico, sobretudo no que tange à tutela dos direitos difusos e à interpretação do acesso à justiça, evidenciando cada vez mais as tutelas dos direitos e garantias dos cidadãos. ${ }^{38}$

A incorporação do termo de ajustamento de conduta no Brasil se deu com a promulgação do Estatuto da Criança e do Adolescen-

36 SAMPAIO, Francisco José Marques. Responsabilidade civil e reparação de danos ao meio ambiente. 2.ed. Rio de Janeiro: Lumen Juris, 1998, p. 229. Apud STEIGLEDER, 2011, p. 211.

37 HOBSBAWN, Eric. O breve século XX 1914-1991, São Paulo: Companhia Letras, 1995, (sem paginação). Apud LOUZADA, Vanessa Vilarino. Do termo de ajustamento de conduta ambiental como meio eficiente de solução de conflitos. 75 f. Monografia (Pós-graduação) - Pós-graduação em Direito Ambiental, Universidade Federal do Paraná, 2013, p. 18.

38 LOUZADA, 2013, p. 18. 
te, o qual permitiu a hipótese de compromisso de ajustamento de conduta, desde que a defesa desses interesses individuais e coletivos estivesse vinculada à proteção da infância e da juventude, conforme disposto no art. 211, da legislação referida. ${ }^{39}$

Nesse viés, a instituição do Código de Defesa do Consumidor (Lei Federal n. 8.078/90), trouxe uma nova perspectiva às relações de consumo, tanto que o ajustamento de conduta acabou vindo a ser utilizado como instrumento de reparação na tutela de direitos transindividuais, como no caso do direito ambiental. Ainda, a nova legislação incluiu a aplicação do compromisso aos direitos coletivos, lhes atribuindo uma eficácia de título extrajudicial, modificando o disposto no parágrafo $6^{\circ}$, do art. 5ํㅜㄹ da Lei da Ação Civil Pública. ${ }^{40}$

Ainda, cumpre ressaltar que a Constituição Federal de 1988deu ao direito ao meio ambiente ecologicamente equilibrado o status de direito difuso fundamental, uma vez que trata-se de um direito atribuído a um sujeito plural ("todos", "coletividade"), enumerando o meio ambiente, de forma taxativa, como digno de proteção e impondo ao poder público e a coletividade o dever de protegê-lo e preservá-lo para as presentes e futuras gerações. Nesse sentido, a lição de Molinaro ${ }^{41}$ :

Do texto constitucional fica bem esclarecido que o ambiente é um direito atribuído a um sujeito plural sobre bem de uso comum. Como res communesomniumé um bem público com um qualificado predicado: atemporalidade. De outro modo, perspectivado como totalidade atributiva6,

39 NERY, Ana Luiza de Andrade. Compromisso de Ajustamento de Conduta: Teoria e análises de casos práticos. 2.ed. São Paulo: Editora Revista dos Tribunais, 2012, p. 111.

40 RODRIGUES, Geisa de Assis. Ação civil Pública e termo de ajustamento de conduta: teoria e prática. Rio de Janeiro: Forense, 2006, p. 2-3.

41 MOLINARO, Carlos Alberto. Breves reflexões sobre os deveres fundamentais socioambientais. Revista Novos Estudos Jurídicos - Eletrônica, Vol. 20, n. 3, set-dez 2015, p. 996. 
caracteriza-se como um macrobem que não se confunde com os bens que o incorporam. Ademais, é insusceptível de apropriação, também indisponível, indivisível, imaterial e de titularidade difusa.

Sendo assim, no que diz respeito à tutela do direito ambiental, a celebração do ajustamento de conduta se torna de extrema importância, pois revela-se um instrumento eficiente de proteção e, sobretudo, prevenção ao meio ambiente, na medida em que se mostra também um eficiente instrumento de tutela inibitória, porquanto pode ser firmado antes mesmo da ocorrência do dano, servindo como instrumento de desestímulo do infrator à prática ou a reiteração do ato ilícito através da possibilidade de imposição de medidas coercitivas ${ }^{42}$.

Nesse sentido, a doutrina constata que o termo de ajustamento de conduta surgiu no direito brasileiro, justamente, como uma forma de aperfeiçoar a tutela metaindividual, tendo como intenção a redução das demandas individuais mediante a resolução de lesões difusas ou coletivas na própria esfera administrativa, isto é, sem precisar judicializar a questão e de forma mais célere solucionar o conflito, tendo como pressuposto básico os direitos fundamentais e os princípios do Estado Democrático de Direito. ${ }^{43}$

Dessa maneira, depois de apresentado um breve histórico do Termo de Ajustamento de Conduta (TAC), bem como sua evolução jurídica até abranger a tutela do direito ambiental, a presente pesquisa se direciona a análise dos aspectos formais e processuais do referido instrumento, a fim de compreender melhor sua aplicação no caso de Mariana/MG.

42 RODRIGUES, op. cit., p. 129.

43 LOUZADA, 2013, p. 20. 


\subsection{ASPECTOS GERAIS DO TAC: CONCEITO, LEGITIMADOS E FORMAS DE CELEBRAÇÃO}

Segundo leciona NERY ${ }^{44}$, pode-se definir o termo de ajustamento de conduta como uma forma de propiciar um procedimento mais célere e efetivo para a resolução dos conflitos, visando priorizar a busca pelo atendimento do interesse público, bem como facilitar a execução das obrigações pactuadas, além de demonstrar uma vasta importância no que se refere ao amparo dos interesses difusos e coletivos.

Portanto, pode-se afirmar, em um sentido amplo, que o termo de ajustamento de conduta tem por objeto a:

conformação às exigências da lei vigente ao momento da ocorrência da ameaça ou da violação do direito transindividual, para proteção ao meio ambiente, consumidor, ordem urbanística, patrimônio cultural, ordem econômica e economia popular, outros interesses difusos e coletivos (Lei LACP), somando-se ainda danos ao patrimônio público e social, prevenção de acidentes do trabalho, defender interesses de população indígena, crianças e adolescentes, pessoas idosas ou portadores de deficiência, investigar abusos do poder econômico, defender contribuintes, apurar falhas da Administração na prestação de serviços, acesso à educação ${ }^{45}$

O objetivo do TAC consiste em adequar a conduta do causador do dano a interesses transindividuais, estabelecendo obrigações de fazer ou de não fazer ${ }^{46}$, da mesma forma que designará a reparação a título de tutela especifica ou reparatória/

\footnotetext{
44 NERY, 2012, p. 112.

45 LOUZADA, op.cit., p. 43.

46 MAZZILli, Hugo Nigro. Compromisso de Ajustamento de Conduta: evolução e fragilidades e atuação do Ministério Público. Revista de Direito Ambiental. [S.1]. vol. 41/2006, p. 93-110, jan-mar/2006, p. 01-02.
} 
compensatória, sempre apreciando a previsão legal vigente e em conformidade com os princípios que regem o ordenamento jurídico brasileiro. ${ }^{47}$

É de grande importância destacar que a pactuação do ajustamento de conduta não possui o condão de excluir a responsabilidade criminal do obrigado, haja vista que a Constituição Federal, em norma expressa, a independência das responsabilidades civil, penal e administrativa em matéria ambiental. ${ }^{48}$

No que se refere a natureza jurídica do TAC, a doutrina não é uníssona. É possível identificar posições distintas que classificam o termo de ajustamento de conduta como ato administrativo negocial; como transação; e como ato jurídico ou acordo extrajudicial.

Hugo Mazzilli ${ }^{49}$ compreende o TAC como um ato administrativo negocial, o qual se consolida através de uma "declaração de vontade do Poder Público coincidente com a do particular (o causador do dano, que concorda em adequar sua conduta às exigências da lei)".

Em contrapartida, Patrícia Pizzol, acredita se tratar de um de ajustamento com natureza de transação, uma vez que existem concessões mútuas entre os celebrantes do ajuste, no entanto, é vedado ao órgão público legitimado a renúncia de direitos transindividuais, o que o transformaria em uma transação de característica sui generis. ${ }^{50}$

Já para Paulo Cezar Pinheiro Carneiro e José dos Santos Carvalho Filho, não há falar em transação, no que se refere à natureza jurídica do TAC, tendo em vista não ser possível transacionar direitos indisponíveis, o que ocorre com aqueles direitos que

47 LOUZADA, op. cit, p. 43.

48 RODRIGUES, 2006, p. 178.

49 MAZZILLI, jan-mar/2006, p. 06.

50 PIZZOL, Patrícia Miranda. Liquidação nas ações coletivas. São Paulo: Lejus, 1998, p. 149-153. Apud LOUZADA, 2013, p. 45. 
estão sujeitos à tutela por meio de ação civil pública, tratando-se, assim, de ato jurídico. ${ }^{51}$

Por fim, Sérgio Shimura classifica o compromisso como acordo extrajudicial, onde o causador ou ameaçador do dano aceita, voluntária ou unilateralmente, às exigências da legislação em vigor, o que, em suma, não se difere de um ato jurídico unilateral, mesmo possuindo uma conotação de acordo. ${ }^{52}$

No que diz respeito aos aspectos formais do termo de ajustamento de conduta, este deverá versar, obrigatoriamente, sobre um objeto lícito, possível e determinável, sob pena de nulidade. 0 ajustamento deverá, também, abranger uma "satisfatória prevenção ou à integral reparação do ilícito ou do dano, tal como seria postulado em sede de ação civil pública". ${ }^{53}$

0 termo terá que conter, também, todos os dados relevantes para a qualificação do compromissário, uma vez que é imprescindível que o órgão representante da coletividade seja bastante cauteloso com os aspectos formais de identificação da parte com quem se firma o compromisso de ajustamento de conduta, para que não haja frustração diante de uma eventual execução, além de fazer constar o lugar e a data em que foi celebrado. ${ }^{54}$ Ainda, deverá ser realizado de forma escrita e em língua vernácula, para que se constitua em título executivo, bem como deverá ser celebrado por órgão público brasileiro. ${ }^{55}$

No que tange aos legitimados à elaboração dos termos de compromisso, o Estatuto da Criança e do Adolescente ${ }^{56}$ (Lei noㅡ

51 LOUZADA, op. cit., p. 45-46.

52 SHIMURA, Sérgio. Tutela coletiva e sua efetividade. São Paulo: Método, 2006, p. 134. Apud LOUZADA, op.cit., p. 46.

53 NERY, 2012, p. 192-193.

54 LOUZADA, 2013, p. 38.

55 RODRIGUES, 2006, p. 192.

56 Art. 210. Para as ações cíveis fundadas em interesses coletivos ou difusos, consideram-se legitimados concorrentemente:

I - o Ministério Público;

II - a União, os estados, os municípios, o Distrito Federal e os territórios; 
8.069/90) e a lei que disciplina a Ação Civil Pública ${ }^{57}$ (Lei no 7.347/85), dispõem que somente os órgãos públicos legitimados a propor ações civis públicas são autorizados a realizar o termo de ajustamento de conduta.

Todavia, embora o $§ 6^{\circ}$, do art. 5ํㅡㄹ da Lei 7.347/85 autorize qualquer um dos legitimados a propor Ação Civil Pública a tomar o compromisso de ajustamento de conduta, Mazzillii ${ }^{58}$ argumenta que as associações civis, sindicatos e fundações privadas não podem, de maneira alguma, firmar o referido compromisso, uma vez que são exploradores de atividades econômicas.

Ainda, destaca-se que embora uma variedade entes públicos estejam legitimados a celebração deTACs, naprática, o ente deverá possuir legitimidade para propor ação civil pública para a tutela

III - as associações legalmente constituídas há pelo menos um ano e que incluam entre seus fins institucionais a defesa dos interesses e direitos protegidos por esta Lei, dispensada a autorização da assembléia, se houver prévia autorização estatutária.

Art. 211. Os órgãos públicos legitimados poderão tomar dos interessados compromisso de ajustamento de sua conduta às exigências legais, o qual terá eficácia de título executivo extrajudicial.

57 Art. 50 Têm legitimidade para propor a ação principal e a ação cautelar:

I - o Ministério Público;

II - a Defensoria Pública;

III - a União, os Estados, o Distrito Federal e os Municípios;

IV - a autarquia, empresa pública, fundação ou sociedade de economia mista;

V - a associação que, concomitantemente:

a) esteja constituída há pelo menos 1 (um) ano nos termos da lei civil;

b) inclua, entre suas finalidades institucionais, a proteção ao patrimônio público e social, ao meio ambiente, ao consumidor, à ordem econômica, à livre concorrência, aos direitos de grupos raciais, étnicos ou religiosos ou ao patrimônio artístico, estético, histórico, turístico e paisagístico. $\S 6^{\circ}$ Os órgãos públicos legitimados poderão tomar dos interessados compromisso de ajustamento de sua conduta às exigências legais, mediante cominações, que terá eficácia de título executivo extrajudicial.

58 MAZZILLI, Hugo Nigro. O inquérito civil: investigações do Ministério Público, compromissos de ajustamento e audiências públicas. São Paulo: Saraiva, 1999, p. 300-301. 
da matéria objeto do TAC. Significa dizer: uma autarquiadirecionada à defesa do meio ambiente possui legitimidade, somente, para firmar compromissosque abrangerem matéria de proteção ambiental, mas não poderá tomar o termo, por exemplo, de um fabricante de veículospara que este realize um recallde seus automóveis que constarem falhas no sistema de freios ${ }^{59}$, pois assim estaria extrapolando sua finalidade temática.

Outro ponto a ser analisado é o momento de celebração do termo de ajustamento de conduta, se necessariamente nos autos de um inquérito civil público, procedimento investigativo promovido pelo Ministério Público e que antecede a propositura de uma ação civil pública, ou se pode ser celebrado em qualquer procedimento administrativo de investigação.

Sendo assim, como já foi vislumbrado, o TAC não é uma atribuição exclusiva do Ministério Público, ao contrário do inquérito civil público e dos poderes de investigação à ofensa dos direitos transindividuais típicos do Parquet, podendo então ser elaborado e celebrado separada e independentemente de um inquérito civil público. Todavia, isso dependerá da matéria a ser tratada no termo para que se observe a legitimidade do órgão público celebrante do TAC, como destacado anteriormente, sob pena de nulidade do ato. ${ }^{60}$

Ainda, tendo em vista o princípio democrático, o TAC deverá ser precedido de uma investigação mínima, que será formulada no procedimento administrativo, inclusive, para facilitar o seu controle social. Da mesma forma, considera-se que o ajuste, quando celebrado através do Ministério Público, deverá ser realizado, indispensavelmente, em uma das etapas do inquérito civil ou do procedimento administrativo investigatório. ${ }^{61}$

59 ANDRADE, Adriano; MASSON, Cleber; ANDRADE, Landolfo. Interesses difusos e coletivos esquematizado. 5.ed. Rio de Janeiro: Forense; São Paulo: Método, 2015, p.225.

60 RODRIGUES, 2006, p. 198.

61 RODRIGUES, 2006, p. 198. 
É importante apontar que o Ministério Público, possui a prerrogativa para celebrar uma modalidade de termo de ajustamento de conduta especial para casos complexos, o chamado compromisso de ajustamento de conduta preliminarouprovisório, o qual consiste na imposição, ao compromissário, de obrigações "voltadas à proteção do interesse que se visa a resguardar, mas que ainda não são suficientes para sua proteção integral". ${ }^{62}$

A título de exemplo, cita-se a súmula 20, do Conselho do Superior do Ministério Público de São Paulo, que, de forma expressa afirma essa prerrogativa funcional, ao possibilitar a adoção do compromisso provisório sempre que houver necessidade de se buscar diligências complementares para a garantia de uma melhor solução ao problema, podendo ser realizada tanto de forma preliminar ao termo definitivo quanto após a sua formalização. ${ }^{63}$

\subsection{DO (DES)CUMPRIMENTO DO TAC}

Primeiramente, retoma-se que a Lei da Ação Civil Pública atribuiua eficácia de título executivo extrajudicial ao termo de ajustamento de conduta, assegurando uma maior facilidade para se efetivar suaexecução em caso de descumprimento dos termos pelo compromissário. Portanto, na hipótese de se tornar necessária sua execução forçada, em razão do descumprimento total ou parcial do TAC, aplica-se o que determinamos arts. $771 \mathrm{e}$ seguintes, do novo Código de Processo Civil (Lei n. 13.105/2015), no que tange aos procedimentos de execução.

No entanto, muito embora não se exija a homologação judicial do termo de conduta, se as partes assim preferirem fazer ou se o mesmo for realizado nos autos de ação civil pública e o juiz efetuar sua homologação, o TAC deixará de ser título extrajudicial e passa-

62 ANDRADE; MASSON; ANDRADE, 2015, p. 230.

63 SÃO PAULO. Ministério Público. Súmulas consolidadas referentes a termo de ajustamento de conduta. Disponível em: <http://www.mpsp.mp.br/portal/page/ portal/conselho superior/sumulas/sumulasTAC $>$. Acesso em: 13.nov.2017. 
rá a ser aplicado como título executivo judicial, devendo ${ }^{64}$, assim, observar o disposto nos artigos 513 e seguintes do novo Código de Processo Civil, no que diz respeito ao cumprimento de sentença.

Sendo assim, no que se refere ao descumprimento do TAC, a Lei 7.347/85 dispõe que serão aplicadas "cominações legais", o que não implica, necessariamente, a aplicação de multas pecuniárias, muito embora esta seja a cominação mais habitual, podendo ser estipuladas tanto para os casos em que o compromissário deixar de satisfazer a totalidade da obrigação (multa compensatória), quanto para as circunstâncias em que não for respeitado o cumprimento dos prazos estipulados no termo (multa moratória). ${ }^{65}$

Neste sentido, o Superior Tribunal de Justiça vem, através dos anos, reforçando o papel das astreintes no direito brasileiro, sendo que a jurisprudência do Tribunal tem dado destaque ao instituto, haja vista se tratar de instrumento para coibir o adiamento indeterminado do cumprimento de obrigação imposta ao compromissário, devendo ser aplicadas à parte que deixar de atender determinada decisão judicial. ${ }^{66}$

Logo, a imposição de uma multa coercitiva é instrumento imprescindível para uma maior efetividade no cumprimento dos termos do TAC por seus signatários, haja vista que a sua indefinição, segundo entendimento do STJ, pode ensejar uma inércia do obrigado em cumprir o encargo que lhe foi dado. Confira-se:

ADMINISTRATIVO E PROCESSUAL CIVIL. ASTREINTES. OBRIGAÇÃO ASSUMIDA CONSENSUALMENTE. TERMO FINAL DE SUA INCIDÊNCIA. EFETIVO CUMPRIMENTO DO TERMO DE AJUSTE DE CONDUTA. 1. A inércia da municipalidade no cumprimento do

64 MAZZILli, Hugo Nigro. A defesa dos interesses difusos em juízo: meio ambiente, consumidor, patrimônio cultural, patrimônio público e outros interesses. 26.ed. São Paulo: Saraiva, 2013, p. 464.

65 LOUZADA, 2013, p. 40.

${ }^{66}$ Ibdem, p. 40. 
pactuado em Termo de Ajustamento de Conduta firmado com o Ministério Público, sobretudo em caso de inadimplemento de obrigação de fazer para a debelação de dano ambiental, justifica a incidência de multa coercitiva até o efetivo cumprimento do encargo consensualmente assumido. 2. A indefinição do termo final da incidência das astreintes é fenômeno resultante da injustificada inércia do própriodevedor da obrigação, no que expressa seu contumaz intento em descumprir o encargo que lhe toca.

3. Agravo interno a que se nega provimento. ${ }^{67}$

Nesse panorama, é fundamental salientar que os órgãos legitimados a formalizar o termo de ajustamento de conduta, quando se tratar de título extrajudicial, devemser bastante cautelosos no que diz respeito à fixação das astreintes, uma vez que a eventual cominação de uma multa sem eficácia não autorizará o juízo da execução a majorá-la, pois, segundo disciplina o parágrafo único, do art. 814, do novo Código de Processo Civil, o juiz possui, somente, a prerrogativa de reduzi-la no caso de excesso na sua imposição.

Essa limitação, todavia, segundoToniolo, parece irrazoável - tendo em vista que vivenciamos cada vez mais um direito processual disciplinado por direitos e garantias fundamentais -que o magistrado não tenha permissão de readequar a aplicação da multa, com o intuito de gerar uma maior efetividade às obrigações de fazer inadimplidas. ${ }^{68}$

Dessa maneira, para que se possa ensejar a coercibilidade necessária, evitando o inadimplemento das cláusulas do ajuste, a fixação das multas deve considerar: "a dimensão do empre-

67 BRASIL, Superior Tribunal de Justiça. Agravo Interno no Recurso Especial $\mathrm{n}^{\circ}$ 1.332.775/MS, Relator Ministro Sérgio Kukina, Primeira Turma, julgado em 15/08/2017, DJe 28/08/2017.

68 OAB. Novo código de processo civil anotado. Porto Alegre: OAB RS, 2015, p.560. 
endimento ou da atividade do compromissário; a extensão do dano ambiental ocasionado e as condições econômicas do compromissário". ${ }^{69}$

Agora, em se tratando do cumprimento de sentença de título judicial, conforme dispõe o $§ 1^{\circ}$, do art. 537, o juiz tem a faculdade de majorar ou reduzir as astreintes quando lhe aparentar ser insuficiente ou excessiva para a efetivação da obrigação, bem como poderá exclui-la quando o obrigado provar "cumprimento parcial superveniente da obrigação ou justa causa para o descumprimento".

Analisados os aspectos jurídicos gerais do termo de ajustamento de conduta, volta-se agora para sua utilização no caso da tragédia ambiental de Mariana/MG.

\section{DA ANÁLISE DO CASO DE MARIANA/MG}

Conforme noticiado toda rede nacional, no dia 05 de novembro de 2015, a cidade mineira de Mariana foi palco, segundo o IBAMA, do maior desastre ambiental da história do país. A barragem de Fundão, pertencente à mineradora Samarco, rompeu-se e provocou o "vazamento de 62 milhões de metros cúbicos $\left(\mathrm{m}^{3}\right)$ de lama de rejeitos de minério, matando 19 pessoas (entre moradores e funcionários da empresa), destruindo centenas de imóveis e deixando milhares de pessoas desabrigadas"70.

Esse vazamento, o qual foi apontado como o maior em volume de material despejado por barragens de rejeitos de mineração até o momento, ocasionou, também, a poluição do Rio Doce e seus danos ambientais se estenderam aos estados do Espírito Santo e da Bahia. ${ }^{71}$ Contabiliza-se que 39 cidades foram afetadas

69 LOUZADA, 2013, p. 40-41.

70 BRANCO, Mariana. O maior desastre ambiental do Brasil, tragédia de Mariana deixou 19 mortos. Disponível em: <http://acervo.oglobo.globo.com/em-destaque/maior-desastre-ambiental-do-brasil-tragedia-de-mariana-deixou-19-mortos-20208009>. Acesso em: 07.jun.2017.

71 BRANCO, Acesso em: 07.jun.2017. 
pelo rompimento da barragem, além disso, 11 toneladas de peixes foram mortos. Devido à extensão da área atingida, gerou-se uma situação de extrema vulnerabilidade da fauna e da flora do Rio Doce. ${ }^{72}$

Destaque-se que conforme reportagem veiculada no sítio do Governo Federal ${ }^{73}$, o aumento da turbidez da água provocou a morte de milhares de peixes e outros animais. Conforme dados do IBAMA, "das mais de 80 espécies de peixes apontadas como nativas antes da tragédia, 11 são classificadas como ameaçadas de extinção e 12 existiam apenas lá". Ainda, um laudo técnico parcial realizado pelo IBAMA, em dezembro de 2015, indica que o nível do impacto foi de tamanha dimensão que se torna impossível estabelecer um prazo de recuperação da fauna local para o reequilíbrio das espécies na bacia. ${ }^{74}$

Em análise laboratorial, realizada após o rompimento das barragenspelo Serviço Autônomo de Água e Esgoto (SAAE), foram constatadas na água do Rio Doce inúmeras "partículas de metais pesados como chumbo, alumínio, ferro, bário, cobre, boro e mercúrio". Conforme apontado no diagnóstico, o rio está oficialmente morto, não possuindo mais nenhuma utilidade, sendo sua água "imprópria para irrigação e consumo animal e humano". ${ }^{75}$

Segundo reportagens, nas cidades onde é instalado este tipo de estrutura (barragens), é habitual que existam sirenes de emergência, com o intuito de alertar a população caso de algum incidente. Em Bento Rodrigues, distrito mais próximo à barragem, não havia esse espécie de sistema de emergencial. A Samarco

72 BRANCO, Acesso em: 07.jun.2017.

73 BRASIL, Governo Federal. Entenda o acidente de Mariana e suas consequências para o meio ambiente. Disponível em: <http://www.brasil.gov.br/meio-ambiente/2015/12/entenda-o-acidente-de-mariana-e-suas-consequencias-para-o-meio -ambiente>. Acesso em: 08.jun.2017.

74 BRASIL, Acesso em: 08.jun.2017.

75 GALILEU, Revista. É oficial: o Rio Doce está completamente morto. Disponível em: <http://revistagalileu.globo.com/Ciencia/Meio-Ambiente/noticia/2015/11/e-oficial-o-rio-doce-esta-completamente-morto.html>. Acesso em: 19.nov.2017. 
informou, ainda, que seu plano de contingência foi apenas alertar aos líderes das comunidades sobre a tragédia. ${ }^{76}$ No entanto, notícias revelaram que, além do plano de emergência ter sido insuficiente, os moradores daquela localidade não teriam recebido quaisquer avisos acerca do acidente ou orientações para deixar a área, pela Samarco. ${ }^{77}$

Ainda, em estudo apontado pela Bowker Associates, uma consultoria de gestão em riscos relativos à construção pesada, nos Estados Unidos, em parceria com o geofísico David Chambers, o incidente ocorrido em Mariana/MG "equivale, praticamente, à soma dos outros dois maiores acontecimentos do tipo já registrados no mundo - ambos nas Filipinas, um em 1982, com 28 milhões de $\mathrm{m}^{3}$; e outro em 1992, com 32,2 milhões de $\mathrm{m}^{3}$ de lama".78

As dezenas de milhões de metros cúbicos $\left(\mathrm{m}^{3}\right)$ com rejeitos despejados pelo rompimento da barragem devastou a localidade de Bento Rodrigues, que teve cerca de $80 \%$ de suas 257 edificações atingidas pela lama. A tragédia só não teve mais vítimas porque alguns funcionários da empresa correram até o vilarejo para alertar parentes e amigos. ${ }^{79}$

Após dez meses da tragédia que assolou Mariana/MG, foi apresentado estudo feito por um corpo técnico contratado pelas empresas poluidoras (Samarco, Vale e BHP Billiton). As conclusões do estudo apontaram uma sucessão de erros, os quais tiveram início em 2009, sendo que já haviam sido constatados defeitos de construção no dreno de fundo reservatório, resultando na revisão do projeto inicial em 2010. Nesse novo projeto estava prevista a construção de um tapete drenante, o qual se destinaria

\footnotetext{
76 BRANCO, Acesso em: 07.jun.2017.

77 BRANCO, Acesso em: 07.jun.2017.

78 OLIVEIRA, Noelle. Desastre de Mariana é o maior acidente ambiental com barragens em 100 anos. Disponível em: <http://agenciabrasil.ebc.com.br/geral/ noticia/2016-01/desastre-em-mariana-e-o-maior-acidente-mundial-com-barragens-em-100-anos>. Acesso em: 07.jun.2017.

79 BRANCO, Acesso em: 07.jun.2017.
} 
a controlar a saturação do reservatório, contudo, os problemas não tiveram solução. ${ }^{80}$

Segundo este último estudo, nos anos de 2011 e 2012, enquanto o novo projeto estava em construção, ocorreu um segundo incidente com a lama, com água chegando a apenas 60 metros da crista da barragem, ao contrário do prenunciado no projeto que previa a criação de uma "praia de areia", que seria de 200 metros. Como consequência disso, a lama novamente se depositou em áreas indevidas. ${ }^{81}$ No desfecho do ano de 2012, aconteceram mais problemas durante o processo de alteamento da barragem:

[...] quando uma galeria do sistema de drenagem se mostrou estruturalmente deficiente e incapaz para suportar mais carga e, por isso, precisaria ser preenchida de concreto e desativa, o alinhamento da barragem na ombreira esquerda foi deslocado de sua posição para que as operações em Fundão fossem mantidas. Esse processo colocou o maciço diretamente em cima das lamas depositadas anteriormente, o que criou condições para que o processo de liquefação ocorresse. ${ }^{82}$

Mesmo diante de tantos problemas as obras para alteamento continuaram e, no ano de 2013, novas intervenções precisaram ser realizadas para reparo de trincas na estrutura da ombreira esquerda da barragem. No ano subsequente, o tapete drenante, construído nos anos de 2011 e 2012, chegou ao seu limite máximo e as lamas por baixo do maciço aceleraram o processo de liquefação das massas de areia depositadas acima desse material. ${ }^{83}$

80 LOPES, Valquiria. Samarco admite falha na barragem que causou tragédia em Mariana. Disponível em: <http:/www.em.com.br/app/noticia/gerais/2016/08/30/ interna_gerais,798841/samarco-admite-falha-na-barragem-que-causou-tragedia -em-mariana.shtml>. Acesso em: 11.jun.2017.

81 LOPES, Acesso em: 11.jun.2017.

82 LOPES, Acesso em: 11.jun.2017.

83 LOPES, Acesso em: 11.jun.2017. 
$\mathrm{Na}$ data de 5 de novembro de 2015, um fator a mais contribuiu para o rompimento da barragem de Fundão. De acordo com o estudo apresentado pelo corpo técnico contratado pelas empresas poluidoras, três pequenos abalos sísmicos foram registrados noventa minutos antes da tragédia e acabaram funcionando como gatilho para que a barragem se rompesse. ${ }^{84}$

No entanto, nas conclusões do referido estudo, os especialistas não apontaram nenhum responsável nem atribuíramculpa a ninguém, tampouco fizeram apontamentos sobre se a empresa Samarco seria capaz de evitar a tragédia se tivesse tomado alguma medida preventiva. ${ }^{85}$

\subsection{DA AÇÃO CIVIL PÚBLICA AOS termos do acordo ${ }^{86}$}

Após a consumação da tragédia de Mariana, foi ajuizada Ação Civil Pública nº 0069758-61.2015.401.3400 pela União Federal, Estado do Espírito Santo, IBAMA e outros órgãos Federais e Estaduais de Conservação do Meio Ambiente contra Samarco Minerações S/A, Vale S/A e BHP Billiton Brasil Ltda., com o intuito de postular medidas urgentes que reparassem os danos socioambientais decorrentes do rompimento da barragem de Fundão e de Santarém, no Complexo Minerário de Germano, Mariana/MG.

Todavia, em razão do conflito de competência, haja vista que já haviam sido distribuídas diversas ações com causas de pedir idênticas e pedidos semelhantes, bem como pelo fato dessas ações terem como causa de pedir o mesmo dano socioambiental,

${ }^{84}$ LOPES, Acesso em: 11.jun.2017.

85 LOPES, Acesso em: 11.jun.2017.

86 As informações constantes no referido título que não foram referências no rodapé, no intuito de evitar tautologia, foram extraídas da movimentação processual da Ação Civil Pública movida pelo Ministério Público contra a Samarco S/A, Vale S/A e BHP Billiton Brasil S.A, vide em: BRASIL, Tribunal Regional Federal da $1^{\text {a }}$ Região. Ação Civil Pública n ${ }^{0}$ 0069758-61.2015.4.01.3400. Seção de Minas Gerais. $12^{\circ}$ Vara Federal de Belo Horizonte. Juiz Titular ItelmarRaydan Evangelista. Pesquisa Processual. Disponível em: $<\underline{\text { http://portal.trf1.jus.br/portaltrf1/ }}$ pagina-inicial.htm $>$. Acesso em: 25.10.2017. 
se tornou necessária a reunião desses processos para julgamento perante o mesmo juízo, a fim de evitar decisões divergentes, logo, em 14/12/2017, a ação foi declinada da $3^{\circ}$ Vara da Seção Judiciária do Distrito Federal para a 12 ${ }^{\text {a }}$ Vara de Belo Horizonte/MG.

Em sede liminar, no agora juízo competente, o magistrado realizou a apreciação dos requerimentos contidos na Ação Civil Pública, em que os autores defendem a responsabilidade da Samarco Mineração S/A, por ser a operadora da barragem de Fundão e, portanto, a poluidora direta, bem como da Vale S/A, por esta ser, também, uma poluidora direta, uma vez que mantinha contrato com a Samarco, o que lhe permitia destinar à barragem rompida os rejeitos de outra área de exploração mineral. Ademais, aduziram a responsabilidade solidária da Vale S/A e da BHP Billiton Brasil S/A, na qualidade de poluidores indiretos, por serem sócios controladores da Samarco Mineração S/A, além de se demonstrar insuficiente o patrimônio da poluidora direta Samarco para o ressarcimento integral do dano socioambiental causado, o qual foi estimado em $\mathrm{R} \$ 20.204 .968 .949,00$ (vinte bilhões, duzentos e quatro milhões, novecentos e sessenta e oito mil, e novecentos e quarenta e nove reais). ${ }^{87}$

87 Segundo entendimento do Ministro Ricardo Villas BôasCueva, do Superior Tribunal de Justiça, as responsabilidades civis direta e indireta pelo dano ambiental, no ordenamento jurídico brasileiro, se dão justamente pela objetividade, integralidade e solidariedade que abrange a responsabilidade civil ambiental e, portanto, não admitindo nenhuma excludente, inclusive no que diz respeito à cadeia empresarial da atividade causadora do feto lesivo (BRASIL, Superior Tribunal de Justiça. Agravo em Recurso Especial no 1.176.330/SC, Relator Ricardo Villas BôasCueva, Terceira Turma, julgado em 30/11/2017, DJe 04/12/2017). Nesse mesmo sentido, complementa-se o entendimento quanto à imputação/ averiguação da responsabilidade pelo dano causado ao meio ambiente, conforme já citado neste mesmo artigo, de que se equiparam aos responsáveis pelo ato lesivo ao meio ambiente: "quem faz, quem não faz quando deveria fazer, quem deixa de fazer, quem não se importa que façam, quem financia para que façam, e quem se beneficia quando os outros fazem" (BRASIL, Superior Tribunal de Justiça. Recurso Especial no 650.728/SC, Relator Herman Benjamin, Segunda Turma, julgado em 23/10/2007, DJe 02/12/2009). Sendo assim, resta clara a razão pela qual as empresas Vale S/A e a BHP Billiton Brasil S/A, também, foram responsabilizadas de forma indireta pelo desastre de Mariana, ocorrido com rompimento das barragens de Fundão e Santarém, em novembro de 2015. 
Ainda, os autores solicitaram diversas medidas urgentes, de natureza cautelar, a fim de realizar uma reparação imediata nas áreas impactadas pelo rompimento das barragens. Da mesma forma, requereram o pagamento, através de depósito judicial, no valor de R\$ 2 bilhões, como garantia das medidas reparatórias às vítimas ${ }^{88} \mathrm{e}$ a decretação da indisponibilidade das licenças de concessões para a exploração de lavra existentes em nome das empresas rés, bem como, outras medidas assecuratórias, a título de tutela antecipada.

Com efeito, em sua decisão, o juiz entendeu que as empresas Vale S/A e BHP Billiton Brasil Ltda., enquanto controladoras da Samarco Mineração S/A, não são somente as beneficiárias das atividades minerais desenvolvidas pela Samarco, mas também corresponsáveis pelas decisões tomadas pela empresa controlada. Portanto, reconheceu, mesmo que em sede liminar, a solidariedade das 3 empresas compreendidas no polo passivo da ação, a Samarco e a Vale como poluidoras diretas, bem como a Vale a BHP Billiton Brasil como poluidoras indiretas.

Quanto às medidas liminares postuladas, o magistrado concedeu: a) à Samarco prazo de 10 dias para impedir (ou comprovar de estancamento) do vazamento de rejeitos da barragem rompida, bem como a comprovar de adoção de medidas de segurança das barragens de Fundão e Santarém; b) às empresas rés10 dias para iniciar a avaliar da contaminação do pescado inorgânico, bem como do risco à saúde humana e a possível toxidade causada pelo consumo do pescado, bem como controlar a proliferação de espécies sinantrópicas (baratas, ratos, etc) e vetores de doenças transmissíveis aos homens e animais próximas as áreas atingidas; c) às empresas rés prazo de 15 dias para apresentar estudo técnico e adotar medidas a fim de impedir que o volume de lama

88 BRASIL, Advocacia Geral da União. Rio Doce: $A G U$ pede depósito imediato de $R \$ 2$ bi para financiar contenção de danos. Disponível em: $<\underline{\text { http://www.agu. }}$ gov.br/page/content/detail/id conteudo/371775 > . Acesso em: 17 nov. 2017. 
lançado no rio transborde para o sistema de lagoas do Rio Doce; d) às empresas rés prazo de 20 dias para realizar estudo de mapeamento dos diferentes potenciais de resiliência dos 1.049 ha diretamente atingidos, com mapeamento da espessura da cobertura da lama, a granulometria, a presença de metais pesados e o PH dos materiais encontrados; e) à Samarco prazo de 30 dias para efetuar o pagamento, através de depósito judicial, no valor de $\mathrm{R} \$ 2.000 .000 .000,00$ (dois bilhões de reais), como garantia das medidas reparatórias; f) decretar a indisponibilidade das licenças de concessões para a exploração de lavra existentes em nome das empresas rés; e, g) às empresas rés prazo de 45 dias para apresentação do plano global de recuperação socioambiental, e prazo de 30 dias para apresentação do plano global de recuperação socioeconômica.Por fim, estipulou-se multa diária de $R \$ 150.000,00$ (cento e cinquenta mil reais) no caso de descumprimento das medidas ordenadas pelo juízo e multa diária de $\mathrm{R} \$ 1.500 .000,00$ (um milhão e quinhentos mil reais) para a hipótese de descumprimento do item "e".

Na data de 04/11/2016, a juíza substituta Rosilene Maria Clemente de Souza Ferreira, despachou relatando que as rés não cumpriram, total ou parcialmente, os itens "a", "d" e "e" da decisão liminar, publicada em 18/12/2015. As empresas rés peticionaram alegando a realização de algumas das medidas e que, também, estavam aguardando a conclusão dos estudos das áreas afetadas para a efetivação das demais obrigações, justamente por se tratar de medidas extremamente complexas. No tocante ao item "e", as empresas poluidoras aduziram que já havia gasto em torno de $\mathrm{R} \$ 1.274 .023 .757,00$ (um bilhão, duzentos e setenta e quatro milhões, vinte e três mil e setecentos e cinquenta e sete reais) com ações emergenciais e reparatórias, tendo apenas depositado a quantia de $\mathrm{R} \$ 800.000 .000,00$ (oitocentos milhões), além disso, entendiam ser exorbitante a decisão judicial que impôs o pagamento de $\mathrm{R} \$ 2.000 .000 .000,00$ (dois bilhões). 
Da análise da alegação, entendeu o juízo que não seria possível provar que a quantia de 1,2 bilhões de reais foi gasta em tais finalidades aduzidas pelas empresas, ademais, o valor não é, em hipótese alguma, exorbitante, uma vez que faz jus diante da dimensão do dano causado pelos infratores e, ainda, o depósito judicial no valor de $\mathrm{R} \$ 2.000 .000 .000,00$ (dois bilhões) servirão para a garantia da execução de medidas definitivas e reparatórias do dano. Por último, estendeu o prazo para o cumprimento das medidas cautelares, bem como o depósito complementar de R $\$$ 1.200.000.000,00 (um bilhão e duzentos milhões de reais), sob pena de multa diária de $\mathrm{R} \$ 1.500 .000,00$ (um milhão e quinhentos mil reais) no caso de descumprimento do depósito.

Em 11/01/2017, o Ministério Público Federal e as empresas rés noticiaram ao judiciário a existência de tratativas com vistas à celebração de uma composição abrangentes, requerendo, assim, a dilação do prazo para o cumprimento da ordem judicial de depósito até o dia 19/01/2017. Uma semana depois, em 26/01/2017, foi celebrada a assinatura deum termo de ajustamento de conduta provisório, bem como determinada a suspensão da complementação do depósito judicial reiterado em decisão anterior.A homologação do referido TAC provisório veio a ser efetivada, somente, em 21/03/2017, um ano e quatro meses após o rompimento da barragem em Mariana/MG.

O magistrado, em seu despacho, descreveu a tragédia de Mariana/MG como um caso de tamanha complexidade fática e jurídica, que o imaginário popular não pode entender, e assegura estarmos "diante da maior tragédia ambiental do país em toda sua história, cujas consequências para o meio ambiente e para a saúde humana, sequer podem ser auferidas ou dimensionadas".

Complementou, ainda, acerca da magnitude do dano pela flagrante impossibilidade, de até aquele momento, não se obter um diagnóstico socioambiental preciso, não havendo conhecimento da real dimensão do dano, tampouco suas consequências 
ambientais e humanas.Sustentou que embora se trate de um direito difuso, portanto indisponível, os $\S \S 1^{\text {o }}$ e $2^{\circ}$, do art. $3^{3}$, da Lei 13.140/2015, admitem a solução consensual de litígio, desde que o acordo seja homologado em juízo. Ademais, o presente TAC provisório objetiva que medidas sejam já implementadas enquanto se busca a "definição de diretrizes reais e parâmetros objetivos" para a elaboração de um novo acordo de forma definitiva.

Nessa senda, o termo de ajustamento provisório determina a implementação de 3 (três) grupos distintos de especialistas para que realizem estudos substanciais, fundamentados em base científica, de modo a auxiliar no diagnóstico socioambiental e socioeconômico, bem como no monitoramento dos programas de reparação dos danos ambientais em andamento.

O Instituto LACTEC (Instituto de Tecnologia para Desenvolvimento) ficou responsável por realizar a coleta, pesquisa e análise dos dados que auxiliem na elaboração do diagnóstico de todos os danos socioambientais causados pelo rompimento da barragem de Fundão. Já Ramboll Brasil Engenharia e Consultoria Ambiental Ltda., ficou responsável por realizar o diagnóstico e monitoramento dos programas em andamento, ou seja, a coleta, pesquisa e análise de dados referentes aos Programas de Reparação Socioambiental e Socioeconômica, bem como o monitoramento e avaliação dos programas mencionados.

Quanto ao diagnóstico socioeconômico, ficou estabelecido que uma instituição, a ser definida a critério do juiz, ficará a responsável por avaliar os danos socioeconômicos ocorridos, bem como por realizar a revisão do mapeamento dos povos indígenas e quilombolas atingidos ao longo do Rio Doce, revisando o cadastro das pessoas e comunidades atingidas pelo rompimento da barragem.Ainda, o responsável pelos estudos socioeconômicos, ficou com a responsabilidade de colaborar para a "realização de consultas prévias, livres e informadas dos povos indígenas e comunidades tradicionais" atingidas, da mesma forma que 
deverá "colaborar para a organização e realização de audiências públicas". Por fim, deverá, também, "prestar auxílio e assistência para a reparação integral dos direitos das comunidades atingidas".

Posto isso, somente a partir do agrupamento desses diagnósticos é que seriam avaliados os termos para um termo de ajustamento de conduta definitivo, visando uma maior eficácia em seus resultados e a integral reparação dos danos e suas inúmeras consequências, objetivando, acima de tudo, um maior benefício à coletividade.

Por fim, tendo em vista se tratar de matéria de tutela coletiva, o juízo determinou a reunião de todos os processos conexos à Ação Civil Pública no 0069758-61.2015.401.3400, ${ }^{89}$ e determinou a extensão de todos os efeitos jurídicos-processuais decorrentes da homologação do termo, a fim de se evitar decisões conflitantes e/ou contraditórias das diversas ações autuadas.

\subsection{DO ACOMPANHAMENTO DA SITUAÇÃO ATUAL DE MARIANA/MG}

Antes de tudo, é importante lembrarmos que o desastre ocorrido em Mariana, com o rompimento das barragens de Fundão e Santarém, se sucedeu na data de 05 de novembro de 2015.

89 Dentre estas se destaca a ação civil pública ajuizada pelo Ministério Público Federal (ACP no 23863-07.2016.4.01.3800), na qual o MPF estima, como valor preliminar de reparação aos danos ambientais, sociais e econômicos, o montante de R \$ 155 bilhões. "Esse valor foi baseado nos gastos já realizados para custeio da reparação dos danos provocados pelo desastre da DeepwaterHorizon, ocorrido no Golfo do México em 2010, conforme reconhece a empresa British Petroleum, responsável pelo vazamento de cerca de 4,9 milhões de barris de óleo, que teria impactado diretamente $180.000 \mathrm{~km}^{2}$ de águas marinhas e matado 11 pessoas", segundo referido em matéria vinculada ao sítio do Ministério Público Federal. Vide: BRASIL. Ministério Público Federal. MPF entra com ação para total reparação dos danos causados pelo rompimento da barragem da Samarco. Disponível em: <http://www.mpf.mp.br/mg/ sala-de-imprensa/noticias-mg/mpf-entra-com-acao-para-total-reparacaodos-danos-sociais-ambientais-e-economicos-causados-pelo-rompimentoda-barragem-da-samarco-1 >. Acesso em: 17 nov. 2017. 
Passados mais de 2 (dois) anos da tragédia o termo definitivo do ajustamento de conduta ainda não se concretizou.

Mesmo após a homologação judicial do acordo provisório, as partes não cumpriram os prazos estipulados em juízo e, ainda, conseguiram postergar cada vez mais a apresentação dos resultados dos diagnósticos exigidos. 0 que era para ser apresentado 60 dias após a homologação do termo provisório, foi, inicialmente, prorrogado por mais 30 dias. Em 29 de junho de 2017, o prazo foi novamente dilatado, devendo as partes ter apresentado os diagnósticos exigidos até a data de 30 de outubro de 2017. No entanto, passada essa última data, as partes postularam novamente a prorrogação do prazo, aduzindo se tratar de matéria de demasiada complexidade, muito embora tenham alegado que estavam em estágio avançado com as tratativas para o acordo definitivo. ${ }^{90}$

Em despacho, o magistrado salientou que o prazo para a apresentação dos estudos socioeconômicos se esgotaram já há algum tempo, demonstrando que as tratativas estão se desenvolvendo em ritmo visivelmente inapropriado para a apresentação de resultados positivos diante da gravidade do caso.Não obstante, o juiz acabou por deferir, mais uma vez, a prorrogação do prazo para a apresentação do diagnóstico socioeconômico, bem como a assinatura dos termos do acordo final, impreterivelmente até a data de 16 de novembro de 2017. ${ }^{91}$

Enquanto não se deslinda o termo de ajustamento de conduta definitivo, a depressão, o abuso de remédios, hostilidade e incertezas rondam os moradores da região atingida pelo rompimento das barragens. Os atingidos aguardam a inauguração

90 BRASIL, Tribunal Regional Federal da $1^{\text {a }}$ Região. Ação Civil Pública $n^{\text {o }}$ 0069758-61.2015.4.01.3400. Disponível em: <http://portal.trf1.jus.br/portaltrf1/ pagina-inicial.htm $>$. Acesso em: 25.10.2017.

91 BRASIL, Tribunal Regional Federal da $1^{\text {a }}$ Região. Ação Civil Pública $n^{\circ}$ 0069758-61.2015.4.01.3400. Disponível em: <http://portal.trf1.jus.br/portaltrf1/ pagina-inicial.htm $>$. Acesso em: 25.10.2017. 
da "nova Bento Rodrigues", programada para março de 2019, contudo, expõem que sequer o terreno foi regularizado ainda ${ }^{92}$.

Além disso, mais de $25 \%$ da população se encontra desempregada, pois suas rendas dependiam diretamente da empresa Samarco, que está com as atividades suspensas desde o desastre e não possui prazo para reestabelecer suas atividades. Os traumas se acumulam e, de acordo com a rede de saúde mental de Mariana, registra-se, em média, 500 (quinhentos) atendimentos por mês à população atingida. ${ }^{93}$

A tragédia, como já foi pontuada anteriormente, deixou 19 mortos e uma devastação de $600 \mathrm{~km}$ (seiscentos quilômetros) de extensão, contudo, até o momento não foram pagas, ainda, nenhuma das principais multas impostas pelos órgãos ambientais, da mesma forma que das 68 (sessenta e oito) penalidades, 67 (sessenta e sete) ainda estão em fase de recurso e somente 1 (uma) está sendo paga, de forma parcelada, correspondendo a $1 \%$ do total. ${ }^{94}$

Segundo dados oferecidos pelo IBAMA, o montante de penalidades aplicadas à Samarco, pelo órgão federal, totaliza o valor de $R$ \$ 344.085.000,00 (trezentos e quarenta e quatro milhões e oitenta e cinco mil reais). A situação se repete com os órgãos estaduais, cujas multas ultrapassam a quantia de $\mathrm{R} \$ 200.000 .000,00$ (duzentos milhões). Contudo, mesmo que aparentemente elevados os valores das sanções administrativas impostas, reportagens trazem à título de comparação, que o lucro líquido somente da Vale, uma das empresas controladoras da Samarco, foi de R\$ 7.089.000.000,00 (sete bilhões e oitenta e nove milhões de reais), isso no primeiro trimestre desse ano. ${ }^{95}$

92 LINHARES, Carolina; MARQUES, José; PRADO, Avener. Medo e depressão marcam atingidos dois anos após tragédia em Mariana. Disponível em: $<\mathrm{http}: / /$ www1.folha.uol.com.br/cotidiano/2017/10/1929165-medo-e-depressao-marcam-a -rotina-em-vilas-afetadas-por-tragedia-em-mariana.shtml> Acesso em: 27.out.2017.

93 LINHARES; MARQUES; PRADO. Acesso em: 27.out.2017.

94 BEDINELLI, Talita. Samarco pagou só $1 \%$ do valor de multas ambientais por tragédia de Mariana. Disponível em: <https://brasil.elpais.com/brasil/2017/08/08/ politica/1502229456_738687.html> Acesso em: 09.nov.2017.

95 BEDINELLI. Acesso em: 09.nov.2017. 
Quanto à esfera penal, 21 (vinte e uma) pessoas foram denunciadas por homicídio, no entanto, a ação criminal, a qual responsabilizou a Samarco, Vale, BHP, VogBR e outras 22 pessoas, esteve suspensa desde o início de julho de 2017, haja vista o questionamento da defesa pela ilicitude das escutas telefônicas apresentadas no processo, tendo sido retomado o andamento processual apenas em 13 de novembro de 2017, quando o juízoa quo indeferiu o pedido das rés, alegando não vislumbrar nenhuma nulidade nos casos apresentados. ${ }^{96}$

Ainda no que tange a ação penal, vale destacar que a denúncia foi oferecida e aceita no dia 18/11/2016. Nela o Ministério Público, acusa 21 (vinte e uma) pessoas de homicídio qualificado com dolo eventual, respondendo, ainda, pelos crimes de "inundação, desabamento, lesão corporal e crimes ambientais". As empresas poluidoras foram igualmente denunciadas por 9 crimes ambientais, além disso, a empresa VogBR e um engenheiro estão respondendo por crime de apresentação de laudo ambiental falso. ${ }^{97}$

Quanto à recuperação das áreas devastadas pela lama, já foram reabilitados $14,6 \mathrm{~km}^{2}$ de rios e margens atingidas. 0 planejamento é de que até 2020 sejam recuperados $20 \mathrm{~km}^{2}$. No que tange às áreas verdes foi realizado, através de medidas emergenciais, a recuperação de $8 \mathrm{~km}^{2}$, tendo sido planejada a reabilitação de $420 \mathrm{~km}^{2}$ até $2026 .^{98}$

${ }_{96}$ G1 MG. Justiça Federal retoma ação criminal que tornou acusados réus por homicídio no desastre de Mariana, diz MPF. Disponível em: <https://g1.globo. $\mathrm{com} / \mathrm{minas}$-gerais/noticia/justica-federal-retoma-acao-criminal-que-tornou-acusados-reus-por-homicidio-no-desastre-de-mariana-diz-mpf.ghtml> Acesso em: 15.nov. 2017.

97 ZUBA, Fernando; CRISTINI, Flávia; ÂNGELO, Pedro. Justiça Federal suspende ação criminal que tornou acusados réus por homicídio no desastre de Mariana. Disponível em: <https://g1.globo.com/minas-gerais/desastre-ambiental-em-mariana/noticia/justica-federal-suspende-acao-criminal-que-tornou-acusados-reus -por-homicidio-no-desastre-de-mariana.ghtml> Acesso em: 01.nov.2017.

98 LINHARES, Carolina; BARBON, Júlia; PLIGER; Marcelo. Depois da lama. Disponível em: $<$ http://arte.folha.uol.com.br/cotidiano/2017/07/05/depois-da-la$\underline{\mathrm{ma} />}$ Acesso em: 09.nov.2017. 
Segundo vistoria feita pelo IBAMA em novembro de 2016, até aquele momento não havia sido feito, pela Samarco, qualquer tipo de intervenção em 49\% das localidades onde são imprescindíveis ações de conservação do solo, mostrando que as medidas adotadas pela poluidora demonstram ser insuficientes para a total contenção dos rejeitos expelidos pelo rompimento das barragens. ${ }^{99}$

0 Greenpeace Brasil alega que muito pouco foi realizado pelas empresas, que as medidas de contenção foram feitas de maneira superficial nas encostas e que o acumulo de rejeitos nos rios continuam. Expõe, ainda, que muitos pescadores atingidos pela tragédia não foram considerados impactados, pois a Samarco alega que possuíam outra fonte de renda. ${ }^{100}$

Como se não bastasse toda a lentidão nas resoluções das esferas civil, administrativa e penal, a mineradora foi a juízo sustentar que a realização das medidas reparatórias e o acordo em tramitação efetuado com o Ministério Público, justificam a absolvição da empresa no que diz respeito aos crimes ambientais aos quais responde em ação penal. ${ }^{101}$

Ainda, no dia 05 de novembro de 2017, o Rio Doce, uma das principais vítimas do rompimento das barragens em Mariana, ingressou com ação inédita na justiça contra o Governo Federal e o Estado de Minas Gerais, onde requereu um plano de prevenção a desastres, buscando a garantia de uma "maior proteção ao rio, seu entorno e a população em geral". ${ }^{102}$

99LINHARES; BARBON; PLIGER. Acesso em 09.nov.2017.

${ }^{100}$ LINHARES; BARBON; PLIGER. Acesso em 09.nov.2017.

${ }^{101}$ MARQUES, José; PRADO, Avener; LINHARES, Carolina. Samarco usa acordo com União para pedir absolvição de crime ambiental. Disponível em: <http:// www1.folha.uol.com.br/cotidiano/2017/10/1929167-samarco-usa-acordo-com-uniao-para-pedir-absolvicao-de-crime-ambiental.shtml> Acesso em: 06.nov.2017.

${ }^{102}$ LOPES, Raquel. Em ação inédita no país, Rio Doce entra na Justiça contra desastre. Disponível em: <https://www.gazetaonline.com.br/noticias/ cidades/2017/11/em-acao-inedita-no-pais-rio-doce-entra-na-justica-contra-desastre-1014106870.html>. Acesso em: 19.nov.2017. 
Segundo Graziella Beck, diretora da Associação Pachamama, responsável pela ação em nome do Rio Doce, a intenção do manejo do processo é que o rio seja considerado um sujeito de direitos, haja vista que o ordenamento jurídico brasileiro ainda não reconheça o direito da natureza. Buscaram, assim, fundamento em tratados internacionais assinados pelo Brasil, a fim de que se quebre o paradigma onde somente o ser humano seja o centro de tudo, e que a própria vida assuma essa posição, afastando o entendimento de que o meio ambiente seja visto, apenas, como um recurso natural ou um bem passível de exploração e apropriação. ${ }^{103}$

Novamente, passado o último prazo estabelecido,as partes, nos autos da ação civil pública no 0069758-61.2015.4.01.3400, comunicaram a celebração de um termo aditivo ao termo de ajustamento de conduta preliminar, definindo questões concernentes ao diagnóstico socioeconômico e sugerindo a alteração da empresa Integratio, responsável pelo referido estudo, para a nomeação de especialistas do Fundo Brasil de Direitos Humanos e a Fundação Getúlio Vargas, devendo estas atuaremem conjunto. ${ }^{104}$

Sendo assim, requereram outra prorrogação de prazo para a entrega dos estudos socioambientais e socioeconômicos, devido à complexidade dos temas abrangidos pelos estudos. Dessa forma, o magistrado abriu prazo, de 5 dias, para os demais legitimados abrangidos pela Lei de Ação Civil Pública a se manifestarem, para após realizar a homologação do termo aditivo, se assim concordarem, bem concedeu prazo para as rés apresentarem os diagnósticos e o termo definitivo até a data de 20/04/2018. ${ }^{105}$

\footnotetext{
${ }^{103}$ LOPES. Acesso em: 19.nov.2017.

${ }^{104}$ BRASIL, Tribunal Regional Federal da $1^{\text {a }}$ Região. Ação Civil Pública n ${ }^{\circ}$ 0069758-61.2015.4.01.3400. Disponível em: <http://portal.trf1.jus.br/portaltrf1/ pagina-inicial.htm>. Acesso em: 20.11.2017.

${ }^{105}$ BRASIL, Tribunal Regional Federal da $1^{\text {a }}$ Região. Ação Civil Pública $n^{\circ}$ 0069758-61.2015.4.01.3400. Disponível em: <http://portal.trf1.jus.br/portaltrf1/ pagina-inicial.htm>. Acesso em: 20.11.2017.
} 
Dessa forma, infelizmente, ao passo que a Samarco e suas sócias parecem tentar se desvencilhar de suas obrigações oriundas de sua negligência, motivada pela obtenção de altos lucros, são os atingidos aqueles que mais sofrem tentando buscar forças para suportar suas perdas, a hostilidade e o preconceito daqueles que os apontam como "vagabundos", que não trabalham e apenas querem "explorar" a Samarco ${ }^{106}$.

\section{CONCLUSÃO}

Considerando todo o exposto nesse artigo, volta-se a reforçar que o intuito da presente pesquisa é responder se o termo de ajustamento de conduta foi um instrumento apropriado para a resolução do desastre de Mariana, bem como se os termos foram razoáveis e se, de fato, a medida foi efetiva na reparação do meio ambiente degradado, levando em consideração a dimensão do dano causado pelas empresas poluidoras.

Pois bem, pode ser observado que a tragédia ocorrida em Mariana/MG, com o rompimento das barragens de Fundão e Santarém aconteceu em novembro de 2015. Assim, chegadoo ano de 2017 e mesmo tendo decorrido mais de 2 (dois) anos do desastre nada ainda foi concretizado.

No início da pesquisa, partiu-se da hipótese de que o compromisso de conduta, por ser uma medida moderna e consensual no que se refere à tutela dos direitos transindividuais, seria uma medida muito mais célere do que a tramitação ordinária de uma ação civil pública, portanto, traria uma maior efetividade na resolução do conflito.

Todavia, muito embora o termo de ajustamento de conduta, por ser um meio consensual, seja um instrumento que acarreta a imposição de medidas de reparação do dano ambiental com mais rapidezem comparação uma ação judicial, no caso em tela, a dimensão da complexidade do dano não coopera para que a

106 LINHARES; MARQUES; PRADO. Acesso em: 27.out.2017. 
definição e imposição de medidas reparatórias ao meio ambiente sejam ágeis e definitivas, bem como, ao que parece, as partes demandadas não têm interesse na busca de uma resolução mais acelerada do problema.

Nesse particular, aliás, é de se louvar a iniciativa junto ao Ministério Público de firmar o termo de conduta, no entanto, a displicência das infratoras diante das sanções das searas administrativa, penal e civil só evidencia a sua procrastinação no desfecho da reparação do meio ambiente lesado.

Com efeito, é de tamanha complexidade e extensão o dano causado que tanto o judiciário quanto o Poder Público não aparentam estar preparados para a definição das medidas reparatórias definitivas, de modo a assegurar uma das ideias norteadoras da responsabilidade civil em matéria ambiental que é a reparação integral do dano. Se por um lado tenha se acertado em tomar um ajustamento de conduta preliminar para estabelecer medidas que permitam identificar com maior precisão a extensão do dano ocorrido, a condução dessa fase de diagnóstico vai em direção contrária a uma promissora solução.

Ora, como relatado no presente estudo,a entrega os estudos socioeconômicos e socioambientais foidiversas vezes adiada. Tais estudos, essenciais para a celebração de um TAC definitivo, deveriam, inicialmente, ser apresentados em maio deste ano, mas passados mais de 6 (seis) meses do primeiro prazo, ainda não foram realizados.

Pode-se afirmar que, até o presente momento, o Poder Judiciário, que homologou o compromisso provisório, bem como os órgãos públicos que o firmaram, não dispõem ainda de elementos concretos que permitam identificar, com razoável margem de certeza, a real dimensão do dano e que tipo de medidas reparatórias são devidas no caso em questão.

À vista disso, como resposta ao problema de pesquisa proposto, conclui-se que, até o presente momento, o instrumento 
jurídico analisado (termo de ajustamento de conduta - TAC), não se mostrou um instrumento efetivo, para assegurar uma rápida imposição de medidas reparatórias aos danos ambientais, sociais e econômicos decorrentes da tragédia de Mariana/MG.

Não obstante o termo de ajustamento de conduta provisório tenha sido uma medida aparentemente apropriada, em face da dimensão da tragédia, o reiterado descumprimento dos prazos e das medidas ajustadas, pelos demandados, acarreta uma sensação de impunidade e desolação que atinge não só às vítimas diretas da tragédia, como também à coletividade como um todo, titular do direito fundamental ao meio ambiente.

\section{REFERÊNCIAS}

AMADO, Frederico Augusto Di Trindade. Direito ambiental esquematizado.6.ed. São Paulo: Método, 2015.

ANDRADE, Adriano; MASSON, Cleber; ANDRADE, Landolfo. Interesses difusos e coletivos esquematizado. 5.ed. Rio de Janeiro: Forense; São Paulo: Método, 2015

ANTUNES, Paulo de Bessa. Direito Ambiental. 14.ed. São Paulo: Atlas, 2012.

BEDINELLI, Talita. Samarco pagou só 1\% do valor de multas ambientais por tragédia de Mariana. Disponível em: <https://brasil.elpais.com/ brasil/2017/08/08/politica/1502229456_738687.html> Acesso em: 09.nov.2017.

BRANCO, Mariana. $O$ maior desastre ambiental do Brasil, tragédia de Mariana deixou 19 mortos. Disponível em: <http://acervo.oglobo.globo. com/em-destaque/maior-desastre-ambiental-do-brasil-tragedia-de-mariana-deixou-19-mortos-20208009>. Acesso em: 07.jun.2017.

BRASIL, Advocacia Geral da União. Rio Doce: AGU pede depósito imediato de $R \$ 2$ bi para financiar contenção de danos. Disponível em: <http:// www.agu.gov.br/page/content/detail/id_conteudo/371775>. Acesso em: 17 nov. 2017.

Constituição Federal, de 05 de outubro de 1988. Brasília, DF, out.1988. Disponível em: <http://www.planalto.gov.br/ccivil_03/constituicao/constituicaocompilado.htm> Acesso em: 23.mar.2017. 
Governo Federal. Entenda o acidente de Mariana e suas consequências para o meio ambiente. Disponível em: <http://www.brasil. gov.br/meio-ambiente/2015/12/entenda-o-acidente-de-mariana-e-suas-consequencias-para-o-meio-ambiente>. Acesso em: 08.jun.2017.

, Lei 6.938, de 31 de agosto de 1981. Política Nacional do Meio Ambiente, Brasília, DF, ago.1981, Disponível em: <http://www.planalto. gov.br/ccivil_03/leis/L6938compilada.htm> Acesso em: 04.abr.2017.

, Lei no 7.347, de 24 de julho de 1985. Ação Civil Pública, Brasília, DF, jul.1985. Disponível em <http://www.planalto.gov.br/ccivil_03/leis/ L7347Compilada.htm> Acesso em: 03.ago.2017.

, Lei no 8.069, de 13 de julho de 1990. Estatuto da Criança e do Adolescente, Brasília, DF, jul.1990. Disponível em: <http://www.planalto. gov.br/ccivil_03/leis/L8069.htm> Acesso em: 03.ago.2017.

Lei no 8.078, de 11 de setembro de 1990. Código de Defesa do Consumidor, Brasília, DF, set.1990. Disponível em: <http://www.planalto. gov.br/ccivil_03/leis/L8078.htm> Acesso em: 03.ago.2017.

, Lei no 13.105, 16 de março de 2015. Código de Processo Civil, Brasília, DF, mar.15. Disponível em: <http://www.planalto.gov.br/ccivil_03/_ato2015-2018/2015/lei/113105.htm> Acesso em: 15.nov.2017.

Ministério Público Federeal. MPF entra com ação para total reparação dos danos causados pelo rompimento da barragem da Samarco. Disponível em: <http://www.mpf.mp.br/mg/sala-de-imprensa/noticias-mg/mpf-entra-com-acao-para-total-reparacao-dos-danos-sociais-ambientais-e-economicos-causados-pelo-rompimento-da-barragem-da-samarco-1>. Acesso em: 17 nov. 2017.

Superior Tribunal de Justiça. Agravo em Recurso Especial no 1.176.330/SC, Relator Ricardo Villas BôasCueva, Terceira Turma, julgado em 30/11/2017, DJe 04/12/2017.

Superior Tribunal de Justiça. Recurso Especial no 605.323/MG, Relator Ministro José Delgado, Relator para Acórdão: Ministro Teori Albino Zavascki, Primeira Turma, julgado em 18/08/2005, DJ 17/10/2005.

Superior Tribunal de Justiça. Recurso Especial no 650.728/SC, Relator Herman Benjamin, Segunda Turma, julgado em 23/10/2007, DJe 02/12/2009.

Superior Tribunal de Justiça. Recurso Especial no 769.753/ SC, RelatorMinistro Herman Benjamin, Segunda Turma, Julgado em 08/09/2009, DJe 10/06/2011. 
Superior Tribunal de Justiça. Agravo Interno no Recurso Especial no 1.332.775/MS, Relator Ministro Sérgio Kukina, Primeira Turma, julgado em 15/08/2017, DJe 28/08/2017.

Tribunal Regional Federal da 1a Região. Ação Civil Pública no 0069758-61.2015.4.01.3400. Seção de Minas Gerais. 12º Vara Federal de Belo Horizonte. Juiz Titular ItelmarRaydan Evangelista. Pesquisa Processual. Disponível em: <http://portal.trf1.jus.br/portaltrf1/pagina-inicial.htm>. Acesso em: 25.10.2017.

FERREIRA. Henrique Felipe. Fundamentos da responsabilidade civil. Dano injusto e ato ilícito. Revista de Direito privado, São Paulo, n. 3, jul./set. 2000 .

FIORILlO, Celso Antônio Pacheco. Curso de direito ambiental brasileiro.12.ed. São Paulo: Editora Saraiva, 2011.

G1 MG. Justiça Federal retoma ação criminal que tornou acusados réus por homicídio no desastre de Mariana, diz MPF. Disponível em: <https:// g1.globo.com/minas-gerais/noticia/justica-federal-retoma-acao-criminal-que-tornou-acusados-reus-por-homicidio-no-desastre-de-mariana-diz-mpf.ghtml> Acesso em: 15.nov.2017.

GALILEU, Revista. É oficial: o Rio Doce está completamente morto. Disponível em: <http://revistagalileu.globo.com/Ciencia/Meio-Ambiente/ noticia/2015/11/e-oficial-o-rio-doce-esta-completamente-morto.html>. Acesso em: 19.nov.2017.

HOBSBAWN, Eric. O breve século XX 1914-1991, São Paulo: Companhia Letras, 1995.

LINHARES, Carolina; BARBON, Júlia; PLIGER; Marcelo. Depois da lama. Disponível em: <http://arte.folha.uol.com.br/cotidiano/2017/07/05/ depois-da-lama/> Acesso em: 09.nov.2017.

, Carolina; MARQUES, José; PRADO, Avener. Medo e depressão marcam atingidos dois anos após tragédia em Mariana. Disponível em: <http://www1.folha.uol.com.br/cotidiano/2017/10/1929165-medo-e-depressao-marcam-a-rotina-em-vilas-afetadas-por-tragedia-em-mariana.shtml> Acesso em: 27.out.2017.

LOPES, Raquel. Em ação inédita no país, Rio Doce entra na Justiça contra desastre. Disponível em: <https://www.gazetaonline.com.br/noticias/ cidades/2017/11/em-acao-inedita-no-pais-rio-doce-entra-na-justica-contra-desastre-1014106870.html>. Acesso em: 19.nov.2017. 
LOPES, Valquiria. Samarco admite falha na barragem que causou tragédia em Mariana. Disponível em: <http://www.em.com.br/app/ noticia/gerais/2016/08/30/interna_gerais,798841/samarco-admite-falha-na-barragem-que-causou-tragedia-em-mariana.shtml>. Acesso em: 11.jun.2017.

LOUZADA, Vanessa Vilarino. Do termo de ajustamento de conduta ambiental como meio eficiente de solução de conflitos. $75 \mathrm{f}$. Monografia (Pós-graduação) - Pós-graduação em Direito Ambiental, Universidade Federal do Paraná, 2013.

MACHADO, Paulo Affonso Leme. Direito Ambiental Brasileiro. 22.ed. São Paulo: Editora Malheiros. 2014.

MARQUES, José; PRADO, Avener; LINHARES, Carolina. Samarco usa acordo com União para pedir absolvição de crime ambiental. Disponível em: <http://www1.folha.uol.com.br/cotidiano/2017/10/1929167-samarco-usa-acordo-com-uniao-para-pedir-absolvicao-de-crime-ambiental. shtml> Acesso em: 06.nov.2017.

MAZZILLI, Hugo Nigro. A defesa dos interesses difusos em juízo: meio ambiente, consumidor, patrimônio cultural, patrimônio público e outros interesses. 26.ed. São Paulo: Saraiva, 2013.

Hugo Nigro. Compromisso de Ajustamento de Conduta: evolução e fragilidades e atuação do Ministério Público. Revista de Direito Ambiental. [S.l]. vol. 41/2006, p. 93-110, jan-mar/2006.

, Hugo Nigro. O inquérito civil: investigações do Ministério Público, compromissos de ajustamento e audiências públicas. São Paulo: Saraiva, 1999.

MILARÉ, Édis. Direito do ambiente: doutrina, jurisprudência, glossário. 5.ed. São Paulo: Editora Revista dos Tribunais, 2007.

MOLINARO, Carlos Alberto. Breves reflexões sobre os deveres fundamentais socioambientais. Revista Novos Estudos Jurídicos - Eletrônica, Vol. 20, n. 3, set-dez 2015, p. 989-1025. Disponível em: <http://siaiap32.univali. br/seer/index.php/nej/article/view/8362>. Acesso em: 11 mar. 2016.

NERY, Ana Luiza de Andrade. Compromisso de Ajustamento de Conduta: Teoria e análises de casos práticos. 2.ed. São Paulo: Editora Revista dos Tribunais, 2012.

OAB. Novo código de processo civil anotado. Porto Alegre: OAB RS, 2015. 
OLIVEIRA, Noelle. Desastre de Mariana é o maior acidente ambiental com barragens em 100 anos. Disponível em: <http://agenciabrasil.ebc.com. br/geral/noticia/2016-01/desastre-em-mariana-e-o-maior-acidente-mundial-com-barragens-em-100-anos>. Acesso em: 07.jun.2017.

PIZZOL, Patrícia Miranda. Liquidação nas ações coletivas. São Paulo: Lejus, 1998.

RIO DE JANEIRO, Declaração do Rio de Janeiro, de 14 de junho de 1992. Conferência das Nações Unidas sobre meio ambiente e desenvolvimento. Rio de Janeiro, RJ, jun.1992, Disponível em: <http://www.scielo.br/pdf/ ea/v6n15/v6n15a13.pdf> Acesso em: 15.mai.2017.

RODRIGUES, Geisa de Assis. Ação civil Pública e termo de ajustamento de conduta: teoria e prática. Rio de Janeiro: Forense, 2006.

RODRIGUES, Marcelo Abelha. Instituições de Direito Ambiental: parte geral. São Paulo: Max Limonad, 2002

SAMPAIO, Francisco José Marques. Responsabilidade civil e reparação de danos ao meio ambiente 2.ed. Rio de Janeiro: Lumen Juris, 1998.

SÃO PAULO. Ministério Público. Súmulas consolidadas referentes a termo de ajustamento de conduta. Disponível em: <http://www.mpsp.mp.br/ portal/page/portal/conselho_superior/sumulas/sumulasTAC $>$. Acesso em: 13.nov.2017.

SARLET, Ingo Wolfgang; FEINSTERSEIFER, Tiago.Princípios do direito ambiental. São Paulo: Saraiva, 2014.

SHIMURA, Sérgio. Tutela coletiva e sua efetividade. São Paulo: Método, 2006.

SOUZA, Carlos Eduardo Silva e. O princípio neminemlaedere e a prevenção dos danos ambientais. [S.l: s.n], 2012, p. 13-14. Disponível em:

<http://www.publicadireito.com.br/artigos/?cod=3f00f874e9837b0e> Acesso em: 15.nov.2017.

STEIGLEDER, Annelise Monteiro. Responsabilidade Civil Ambiental: As dimensões do dano ambiental no direito brasileiro. 2.ed. Porto Alegre: Livraria do Advogado Editora, 2011.

SIRVINSKAS, Luís Paulo. Manual de direito ambiental.12.ed. São Paulo: Saraiva, 2011.

Luís Paulo. Tutela constitucional do meio ambiente. São Paulo: Saraiva, 2008. 
YOSHIDA, Consuelo Yatsuda Moromizato. A efetividade e eficiência ambiental dos instrumentos econômicos-financeiros e tributários. Ênfase na prevenção. A utilização econômica dos bens ambientais e suas implicações. In: TÔRRES, Heleno Taveira (Org.). Direito tributário ambiental. São Paulo: Malheiros, 2005.

ZUBA, Fernando; CRISTINI, Flávia; ÂNGELO, Pedro. Justiça Federal suspende ação criminal que tornou acusados réus por homicídio no desastre de Mariana. Disponível em: <https://g1.globo.com/minas-gerais/ desastre-ambiental-em-mariana/noticia/justica-federal-suspende-acao-criminal-que-tornou-acusados-reus-por-homicidio-no-desastre-de-mariana.ghtml> Acesso em: 01.nov.2017. 